Article

\title{
The Summer Surface Energy Budget of the Ice-Free Area of Northern James Ross Island and Its Impact on the Ground Thermal Regime
}

\author{
Klára Ambrožová *(i), Filip Hrbáček ${ }^{(1)}$ and Kamil Láska@ \\ Department of Geography, Faculty of Science, Masaryk University, Kotlářská 267/2, 60200 Brno, Czech Republic; \\ filiphrbacek@mail.muni.cz (F.H.); laska@sci.muni.cz (K.L.) \\ * Correspondence: ambrozova.kl@mail.muni.cz
}

Received: 26 July 2020; Accepted: 15 August 2020; Published: 18 August 2020

\begin{abstract}
Despite the key role of the surface energy budget in the global climate system, such investigations are rare in Antarctica. In this study, the surface energy budget measurements from the largest ice-free area on northern James Ross Island, in Antarctica, were obtained. The components of net radiation were measured by a net radiometer, while sensible heat flux was measured by a sonic anemometer and ground heat flux by heat flux plates. The surface energy budget was compared with the rest of the Antarctic Peninsula Region and selected places in the Arctic and the impact of surface energy budget components on the ground thermal regime was examined. Mean net radiation on James Ross Island during January-March 2018 reached $102.5 \mathrm{~W} \mathrm{~m}^{-2}$. The main surface energy budget component was the latent heat flux, while the sensible heat flux values were only $0.4 \mathrm{~W} \mathrm{~m}^{-2}$ lower. Mean ground heat flux was only $0.4 \mathrm{Wm}^{-2}$, however, it was negative in $47 \%$ of January-March 2018, while it was positive in the rest of the time. The ground thermal regime was affected by surface energy budget components to a depth of $50 \mathrm{~cm}$. The strongest relationship was found between ground heat flux and ground surface temperature. Further analysis confirmed that active layer refroze after a sequence of three days with negative ground heat flux even in summer months. Daily mean net radiation and ground heat flux were significantly reduced when cloud amount increased, while the influence of snow cover on ground surface temperature was negligible.
\end{abstract}

Keywords: James Ross Island; Antarctica; ice-free area; energy budget; ground temperature; permafrost

\section{Introduction}

Polar regions with their vast ice-sheets are important climatic factors influencing the climate of the whole planet. The white surface of glaciers in Antarctica and in the Arctic has an albedo of up to $90 \%$ [1], thereby reflecting incoming shortwave radiation and reducing the amount of energy available to the Earth. In the Antarctic, the net amount of incoming solar radiation further affects the grade of turbulent fluxes, atmospheric circulation on a large scale and, as a consequence, the energy budget of the whole planet.

More than $99 \%$ of Antarctica is covered by ice [2], but the ice-free area is further predicted to enlarge [3-5], especially in the Antarctic Peninsula (AP) region. Despite the fact that warming in the AP region has decelerated or even been absent since the 2000s, large decadal [6] and spatial variability in air temperature [7] was found to be a typical feature in this area. Therefore, it does not necessarily indicate a return to a colder climate from a long-term perspective [8].

Most studies have analysed the surface energy budget over sea-ice, snow and ice-covered areas (e.g., [9-12]). Ice-free areas, such as in the AP region, on the other hand, have received less attention. Choi et al. [13] reported that the mean monthly net radiation on an ice-free area on King George Island 
(KGI) was more than two-times larger than the values reported for glaciers in the AP region $[9,10,14]$. Unlike over ice-covered areas, ice-free ground in high latitudes can also be a heat source for the atmosphere [15]. Furthermore, coastal sites are affected by sea proximity, for instance by increased moisture availability for sublimation when the sea is free of ice [16]. However, studies on the surface energy budget in ice-free areas have failed to agree on how the energy is portioned into turbulent and ground heat fluxes $[13,15,17]$, which may be connected to the loss of the low-frequency fluctuation part of fluxes [18]. Thus, further research might help explain the discrepancies.

Moreover, the surface energy budget in cold regions is, to a large extent, affected by snow cover (e.g., [19]). Net radiation in polar regions is limited due to the existence of snow and ice-covered areas, which have up to six times larger albedo compared with bare surfaces [1]. Furthermore, the heat exchange between the ground and the atmosphere is lowered because of snow insulation [20]. Apart from that, reduced ground heat loss weakens the soil temperature decrease [21,22]. Knowledge on how the surface energy budget influences the Antarctic ground thermal regime and how its interaction with snow cover modifies the ground temperature remains limited [17]. Nevertheless, it would be beneficial for improving the knowledge on energy fluxes, weather forecast validation and improvements in the temporal and spatial resolution of numerical models [13].

Surface energy budget studies from ice-free areas in Antarctica only relate to South Shetland Archipelago [13,17]. To the best of our current knowledge, no surface energy budget research has been carried out on the north-eastern side of the AP. Yet, the largest ice-free area, the Ulu Peninsula on James Ross Island (JRI), lies in this region. The sparse vegetation coastal areas of northern JRI resemble semi-desert conditions, such as in Svalbard or Greenland, in terms of vegetation cover, soil and water content $[23,24]$.

The lack of data increases the level of uncertainty about regional climate projections which are also crucial to the assessment of the response of biotic and abiotic components of Antarctic terrestrial ecosystems. The climatic conditions on the eastern side of the AP are known to differ from the western side (e.g., [25]). Correspondingly, the link between the active layer thickness and the surface energy budget in the eastern AP region remains unknown. The main objectives of this study are:

1. To quantify the summer surface energy budget over the ice-free area on the Ulu Peninsula;

2. To identify the connection between components of the surface energy budget and verify if the energy fluxes differ between the western and eastern side of the AP; and

3. To determine the effect of snow cover and cloudiness on the surface energy budget and ground thermal regime.

\section{Material and Methods}

\subsection{Study Site and Instrumentation}

The Ulu Peninsula, covering $552 \mathrm{~km}^{2}$ (see [26]), is the largest ice-free area in the AP region. JRI lies to the south-east of the tip of the AP (Figure 1a), with a prevailing easterly flow often modified by the AP orography in relation to the southern and south-western winds [27]. Consequently, the local climate on JRI is characterized by a $4-5{ }^{\circ} \mathrm{C}$ lower mean air temperature compared to the north-western AP [28]. The study site was situated at 10 meters above sea level ( $\mathrm{m}$ a.s.l.) on a Holocene marine terrace in the northern part of the Ulu Peninsula (Figure 1). The Johann Gregor Mendel Station is located approximately $100 \mathrm{~m}$ to the north-east of the meteorological tower and a sonic anemometer, while the seashore is about $150 \mathrm{~m}$ to the north. The area is composed of dry sandy ground (about 10\% moisture) underlain by continuous permafrost with an active layer of thickness between 50 and $65 \mathrm{~cm}$ [23]. 
(a)

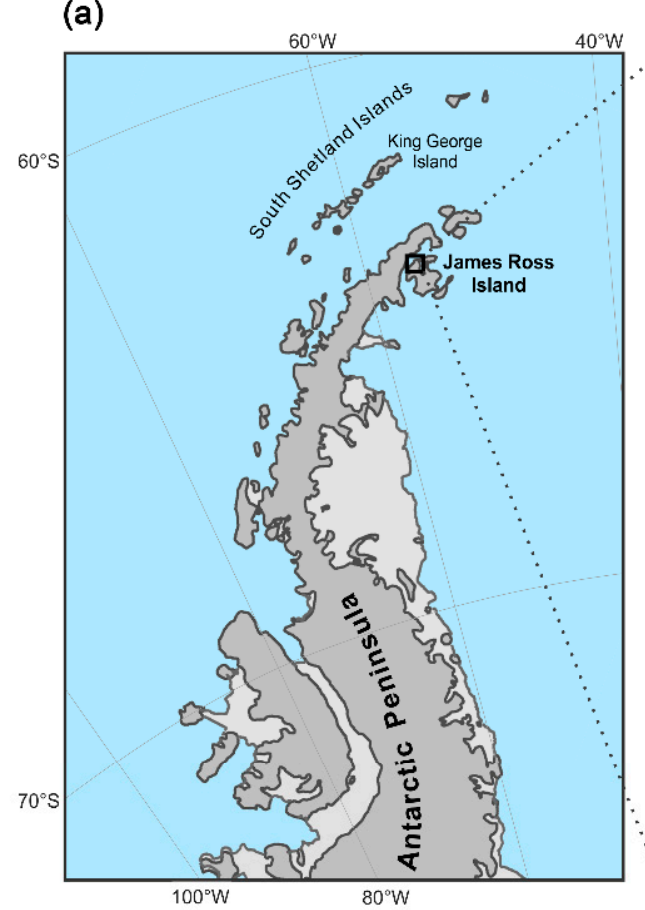

(b)

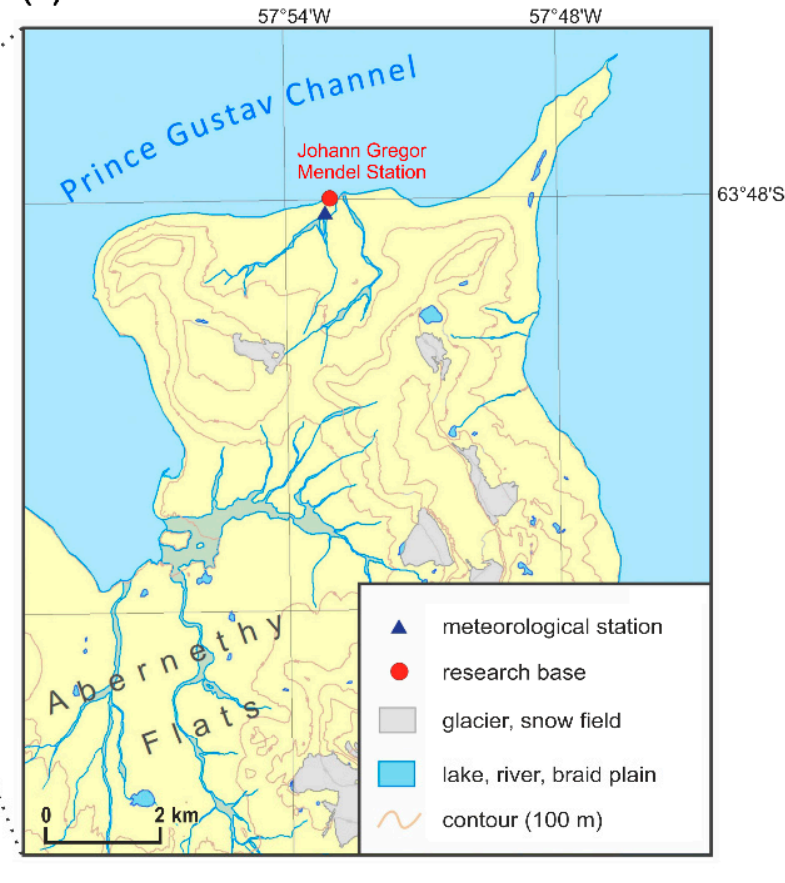

(c)

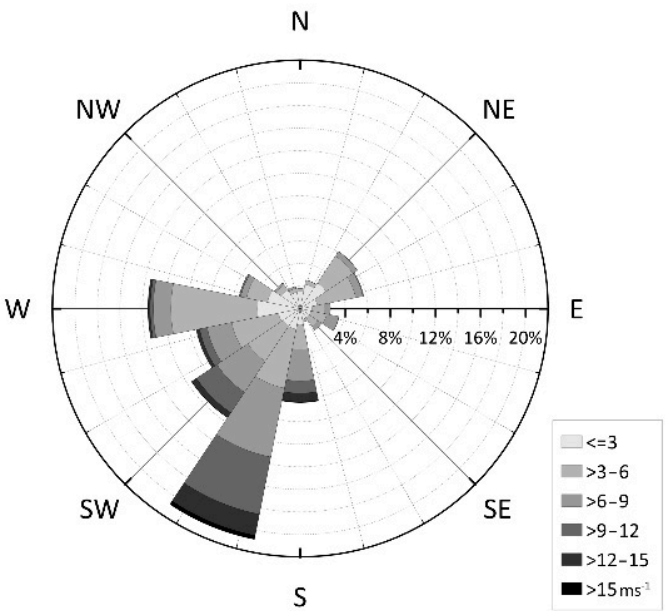

Figure 1. Antarctic Peninsula (AP) region (a), measuring site on Ulu Peninsula, James Ross Island (b) and wind rose representing wind frequencies with respect to their wind speed from study site for period from 23 January to 21 March, 2018 (c).

The measurements were carried out between 23 January and 21 March, 2018 (58 days). Details on the instruments used for measurements are in Table 1 and they were all temporarily installed at one site. For the latent heat flux calculation [29], we used the measurements of 2-m air temperature, relative humidity and surface ground temperature measurements. As only relative humidity was measured, 2-m specific humidity was calculated with the use of air temperature and atmospheric pressure data. Furthermore, vertical kinematic eddy heat flux, Monin-Obukhov length and virtual temperature from sonic anemometer were also included in the latent heat flux calculation. The ground surface temperature was defined as the ground temperature at a depth of $2 \mathrm{~cm}$. 
Table 1. Overview of meteorological parameters ("Parameter") measured on James Ross Island during 23 January-20 March, 2018. In the "Height/Depth" column, positive numbers refer to height above the ground, while negative numbers refer to depth.

\begin{tabular}{|c|c|c|c|c|c|c|}
\hline Parameter & Instrument & Company & $\begin{array}{l}\text { Height/Depth } \\
\text { (m) }\end{array}$ & Accuracy & $\begin{array}{l}\text { Measuring } \\
\text { Interval }\end{array}$ & $\begin{array}{c}\text { Recording } \\
\text { Interval }\end{array}$ \\
\hline Net radiation & $\begin{array}{l}\text { CNR4 Net } \\
\text { Radiometer }\end{array}$ & $\begin{array}{l}\text { Kipp Zonen, } \\
\text { the Netherlands }\end{array}$ & 1 & $\begin{array}{c}\text { Longwave } \\
\text { radiation: } \pm 10 \% \text {, } \\
\text { Shortwave } \\
\text { radiation: } \pm 4 \%\end{array}$ & $10 \mathrm{~s}$ & $5 \mathrm{~min}$ \\
\hline $\begin{array}{c}\text { Wind } \\
\text { components }\end{array}$ & $\begin{array}{l}\text { USA-1 Sonic } \\
\text { Anemometer }\end{array}$ & Metek, Germany & 2 & $0.1 \mathrm{~ms}^{-1}$ or $2 \%$ & $10 \mathrm{~s}^{-1}$ & $5 \mathrm{~min}$ \\
\hline $\begin{array}{l}\text { Ground heat } \\
\text { flux }\end{array}$ & $\begin{array}{l}\text { HFP01 heat flux } \\
\text { plates }\end{array}$ & $\begin{array}{c}\text { Huksefluks, } \\
\text { the Netherlands }\end{array}$ & -0.05 & $\pm 20 \%$ & $30 \mathrm{~min}$ & $30 \mathrm{~min}$ \\
\hline Air temperature & EMS33H Sensor & $\begin{array}{c}\text { EMS Brno, } \\
\text { Czech Republic }\end{array}$ & 2 & $\pm 0.15^{\circ} \mathrm{C}$ & $10 \mathrm{~s}$ & $5 \mathrm{~min}$ \\
\hline $\begin{array}{l}\text { Relative } \\
\text { humidity }\end{array}$ & EMS33H Sensor & $\begin{array}{c}\text { EMS Brno, } \\
\text { Czech Republic }\end{array}$ & 2 & $\pm 1 \%$ & $10 \mathrm{~s}$ & $5 \mathrm{~min}$ \\
\hline $\begin{array}{l}\text { Atmospheric } \\
\text { pressure }\end{array}$ & TMAG & $\begin{array}{c}\text { CRESSTO, } \\
\text { Czech Republic }\end{array}$ & 1 & $\pm 2 \mathrm{~Pa}$ & $10 \mathrm{~s}$ & $5 \mathrm{~min}$ \\
\hline Snow depth & $\begin{array}{l}\text { Ultrasonic snow } \\
\text { depth sensor }\end{array}$ & $\begin{array}{l}\text { Judd Comm., } \\
\text { USA }\end{array}$ & 1 & $\pm 1 \mathrm{~cm}$ & $2 \mathrm{~h}$ & $2 \mathrm{~h}$ \\
\hline $\begin{array}{l}\text { Ground surface } \\
\text { temperature }\end{array}$ & $\begin{array}{l}\text { PT100/8 resistance } \\
\text { thermometer }\end{array}$ & $\begin{array}{c}\text { EMS Brno, } \\
\text { Czech Republic }\end{array}$ & $\begin{array}{l}-0.02,-0.05 \\
-0.10,-0.20 \\
-0.50,-0.75\end{array}$ & $\pm 0.15^{\circ} \mathrm{C}$ & $30 \mathrm{~min}$ & $30 \mathrm{~min}$ \\
\hline
\end{tabular}

\subsection{Data Processing and Analysis}

The surface energy budget of an ice-free surface can be written as:

$$
\mathrm{Q}_{\text {net }}=\mathrm{Q}_{\mathrm{G}}+\mathrm{Q}_{\mathrm{H}}+\mathrm{Q}_{\mathrm{E}}+\mathrm{C}
$$

where $Q_{\text {net }}$ is the net radiation, $Q_{G}$ is the ground heat flux, $Q_{H}$ is the sensible heat flux, $Q_{E}$ is the latent heat flux and $C$ is the residual. The $Q_{n e t}$ has the following components:

$$
\mathrm{Q}_{\text {net }}=\mathrm{Q}_{\mathrm{Snet}}+\mathrm{Q}_{\mathrm{Lnet}}=\mathrm{Q}_{\mathrm{S} \downarrow}+\mathrm{Q}_{\mathrm{S} \uparrow}+\mathrm{Q}_{\mathrm{L} \downarrow}+\mathrm{Q}_{\mathrm{L} \uparrow}
$$

where $\mathrm{Q}_{\text {snet }}$ is the net shortwave flux consisting of incoming $\left(\mathrm{Q}_{\mathrm{s} \downarrow}\right)$ and outgoing $\left(\mathrm{Q}_{\mathrm{s} \uparrow}\right)$ shortwave radiation, while $\mathrm{Q}_{\mathrm{Lnet}}$ is the net longwave flux, which can be divided into incoming $\left(\mathrm{Q}_{\mathrm{L} \downarrow}\right)$ and outgoing $\left(\mathrm{Q}_{\mathrm{L} \uparrow}\right)$ longwave radiation.

All of the measured data were processed as 30-min averages. The $Q_{S \downarrow}$ measurements were further corrected with the use of a more precise CM11 pyranometer (Kipp and Zonen). Simple linear regression was used for adding the relative deviation to CNR4 measurement [30]. Surface albedo was calculated daily as the ratio of $Q_{S \uparrow}$ and $Q_{S \downarrow}$ in the $3 h$ closest to the maximum of $Q_{S \downarrow}$ in order to avoid measurement unreliability under large solar zenith angles and low flux magnitudes.

Ground heat flux measurement was corrected using the calorimetric method [31,32] as follows:

$$
\mathrm{G}_{\mathrm{i}-1}=\delta \mathrm{z}_{\mathrm{i}} \mathrm{C}_{\mathrm{i}}\left(\frac{\partial \mathrm{T}_{\mathrm{i}}}{\partial \mathrm{t}}\right)+\mathrm{G}_{\mathrm{i}}
$$

where $G_{i-1}$ is the heat flux density at the top of a layer, here at a depth of $2 \mathrm{~cm}, \delta z_{i}$ is the layer thickness $(3 \mathrm{~cm}), \mathrm{C}_{\mathrm{i}}$ is the volumetric heat capacity for the layer $\left(1.17 \mathrm{MJ} \mathrm{m}^{-3} \mathrm{~K}^{-1}\right.$ defined for the area by Hrbáček et al. [23]), $\partial \mathrm{T}_{\mathrm{i}} / \partial \mathrm{t}$ is the rate of a 30-min change in the mean layer temperature and $\mathrm{G}_{\mathrm{i}}$ is the heat flux density at the bottom of the layer at a depth of $5 \mathrm{~cm}$.

The sensible heat flux was calculated from sonic anemometer using the eddy covariance technique (e.g., [33]). However, it needs to be noted that when the term "sensible heat flux" is used in this study, it is the buoyancy flux, which was calculated instead of true sensible heat flux due to the absence of fast-response moisture measurements [34]. Sensible heat fluxes of 30-min average were calculated only if 
more than $54 \%$ of the measurement were available. Consequently, $<2 \%$ of sensible heat flux data were missing. Latent heat was calculated as in Langer et al. [29]. Briefly, latent heat flux was estimated as:

$$
\mathrm{Q}_{\mathrm{E}}=-\frac{\rho_{\mathrm{air}} \mathrm{L}_{\mathrm{lg}}}{\mathrm{r}_{\mathrm{a}}}\left(\overline{\mathrm{q}}\left(\mathrm{z}_{\mathrm{m}}\right)-\overline{\mathrm{q}}\left(\mathrm{z}_{0}\right)\right)
$$

where $\rho_{\text {air }}$ is the density of air, $\mathrm{L}_{\mathrm{lg}}$ is the latent heat of vaporization of water, $\mathrm{r}_{\mathrm{a}}$ is atmospheric resistance, $q$ is specific humidity, $z_{m}$ is measurement height and $z_{0}$ is roughness length. Roughness length was originally chosen to be $10^{-3} \mathrm{~m}$ over bare ground and $10^{-4} \mathrm{~m}$ over a snow-covered surface [35,36], but due to unrealistically high values of latent heat flux, they were both lowered by one order to $10^{-4}$ and $10^{-5} \mathrm{~m}$, respectively. The atmospheric resistance $\mathrm{r}_{\mathrm{a}}$ was calculated as in formula D4 in Langer et al. 2011 [29]. Specific humidity at the surface $\mathrm{q}\left(\mathrm{z}_{0}\right)$ was derived from the surface temperature using the Magnus formula [37].

Latent heat flux measurements were only available for $92 \%$ of the study period. For all surface energy budget components, daily and weekly means were calculated if $<20 \%$ were missing, hence the loss of daily mean fluxes on 8 February and 12-14 March, 2018 (Figure 2).
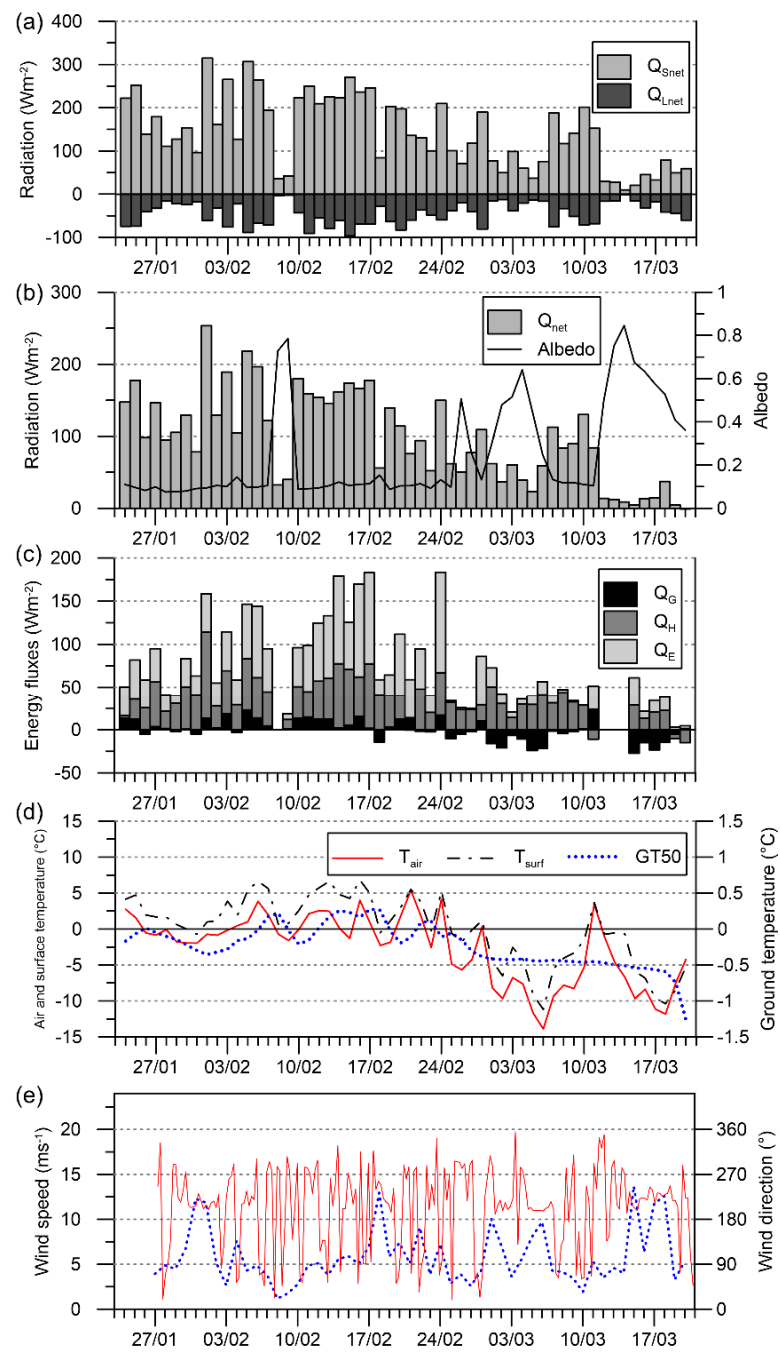

Figure 2. Daily averages of (a) net shortwave radiation $\left(\mathrm{Q}_{\text {Snet }}\right)$, net longwave radiation $\left(\mathrm{Q}_{\mathrm{Lnet}}\right)$, (b) net radiation $\left(\mathrm{Q}_{\text {net }}\right)$ and albedo, (c) ground heat flux $\left(\mathrm{Q}_{\mathrm{G}}\right)$, sensible heat flux $\left(\mathrm{Q}_{\mathrm{H}}\right)$ and latent heat flux $\left(\mathrm{Q}_{\mathrm{E}}\right)$, (d) air temperature $\left(\mathrm{T}_{\text {air }}\right)$, ground surface temperature $\left(\mathrm{T}_{\text {surf }}\right)$ and ground temperature at depth of $50 \mathrm{~cm}$ $\left(\mathrm{GT}_{50}\right)$, (e) wind speed (WS) and wind direction (as six-hourly immediate values, WD). Note that latent heat flux was calculated. 
The data were mostly analysed and compared as daily means; 30-min averages were only examined in Table A1 and day-long case studies in order to determine the influence of snow and cloudiness on the surface energy budget (Section 3.4). For the correlation analysis (Section 3.3), Spearman's rank correlation coefficient was used due to non-normal distributions of some data. Simple linear regression was employed for calculating regression function in Section 3.3. The following convention was used: the net radiation components were considered positive if energy transport was directed towards the ground surface; the turbulent and ground heat fluxes were denoted as positive if energy transport was directed away from the ground surface.

For the case studies, it was necessary to determine a cloudy and a clear-sky day. We only had three categories: clear sky, cloudy and overcast. Cloudiness was derived from a combination of hemispherical photos and $\mathrm{Q}_{\mathrm{S} \downarrow}$ measurements. We calculated the mean daily ratio of $\mathrm{Q}_{\mathrm{S} \downarrow}$ to extra-terrestrial radiation (simply approximated from solar constant and solar zenith angle) in hourly intervals. We then estimated that if the daily mean ratio was above 0.6 , the sky was (mostly) clear. If the ratio was below 0.4 , the day was overcast. Ratios between 0.4 and 0.6 meant a cloudy day.

\subsection{Measurement Accuracy}

The residual term $C$ in our study was $36.1 \pm 104.0 \mathrm{~W} \mathrm{~m}^{-2}$ (Table A1), indicating that errors prevented surface energy budget closure. Unlike the measurements from KGI, where $C$ was not determined but was contained within $\mathrm{Q}_{\mathrm{H}}[17]$ or $\mathrm{Q}_{\mathrm{G}}[13]$, we tried to limit the uncertainty by calculating unmeasured $\mathrm{Q}_{\mathrm{E}}$. Non-zero $C$ has been almost unavoidable in surface energy budget studies from polar regions [29,38], even though errors should have been cancelled out unless there was a systematic error. In our case, $35 \%$ of $Q_{n e t}$ was allocated to neither $Q_{G}$ nor the turbulent fluxes due to a combination of multiple measurement errors.

Firstly, the measurement accuracy of the CNR4 for longwave radiation of $\pm 10 \%$ might have increased the values of $Q_{\text {net }}$ (Table 2). Moreover, Westermann et al. [38] pointed out that uncertainty about albedo under conditions with patches of snow and bare-ground could be up to 0.1 , which would further lower or raise $\mathrm{Q}_{\text {net }}$ by 3.4\%.

Secondly, the eddy covariance technique requires stationarity. However, complex orography around the measuring site was prone to the development of local circulation patterns [36]. That could have led to systematic underestimation of $Q_{H}$ up to 25\% [39], while the use of buoyancy flux as $Q_{H}$ means that another $10 \%$ might need to be added to $\mathrm{Q}_{\mathrm{H}}$ [34].

The error in $\mathrm{Q}_{\mathrm{E}}$ was difficult to assess because no comparable measurements existed. Nevertheless, $\mathrm{Q}_{\mathrm{E}}$ calculating depended strongly on the correct choice of $\mathrm{z}_{0}$. In this study, using the values for snow-covered surfaces and bare ground according to current knowledge $[35,36]$ could lead to an increase of $\mathrm{Q}_{\mathrm{E}}$ up to 33\%. On the other hand, as both Prosek et al. [17] and Choi et al. [13] reported mean $\mathrm{Q}_{\mathrm{E}} \sim \mathrm{Q}_{\mathrm{H}}$, it is likely that the error is smaller. Even though the maximum uncertainty in $\mathrm{Q}_{\mathrm{G}}$ estimation caused by instrument accuracy could have been up to $\pm 20 \%$, the mean value of $Q_{G}$ was below $1 \mathrm{~W} \mathrm{~m}^{-2}$. As a result, the error in $\mathrm{Q}_{\mathrm{G}}$ would not contribute significantly to $\mathrm{C}$.

Finally, individual energy budget components were measured on different spatial scales. $Q_{G}$ was derived from a point measurement and radiation sensors had a footprint area of several square meters. For the sonic anemometer at a height of $2 \mathrm{~m}, 60 \%$ of the flux might have come from an area with a radius of $75 \mathrm{~m}$ or larger [40]. During high wind speeds, the turbulent eddies (and derived energy fluxes) measured by the sonic anemometer were coming from the Bohemian Stream Catchment (see Figure 1 and Section 3.1), where the ground was waterlogged or moister than close to the meteorological tower. Consequently, more energy was allocated to $\mathrm{Q}_{\mathrm{E}}$ in the area from which the turbulence was coming, influencing the residual term $\mathrm{C}$.

Considering the above-mentioned errors, the magnitude of $C$ could be explained by the uncertainty inherited from methods of measurements, the landscape diversity around the measuring site and the choice of parameters in the calculation. Essential for future experiment concept and better accuracy 
of eddy-covariance method could be two-level humidity measurement or krypton hygrometer for measuring water vapour fluctuations with a high-frequency sampling rate.

Table 2. Probable error of measurement for different fluxes in this study.

\begin{tabular}{cccc}
\hline Flux & Error (\%) & Reason & Reference \\
\hline $\mathrm{Q}_{\mathrm{L} \downarrow}\left(\mathrm{Q}_{\mathrm{net}}\right)$ & 10 & Measurement accuracy for longwave radiation & CNR4 Net Radiometer manual \\
$\mathrm{Q}_{\text {net }}$ & 3.4 & Spatial heterogeneity of albedo around the measuring site & {$[38]$} \\
$\mathrm{Q}_{\mathrm{H}}$ & 25 & Local circulation systems formation due to complex orography & {$[39,41]$} \\
$\mathrm{Q}_{\mathrm{H}}$ & 10 & Use of buoyancy flux instead of true sensible heat flux & {$[34]$} \\
$\mathrm{Q}_{\mathrm{E}}$ & 33 & Choice of $\mathrm{z}_{0}$ (see comment in the text) & Sensitivity testing \\
$\mathrm{Q}_{\mathrm{G}}$ & 20 & Measurement accuracy of the instrument & HFP01 heat flux plate manual \\
$\mathrm{Q}_{\mathrm{H}}, \mathrm{Q}_{\mathrm{E}}, \mathrm{Q}_{\mathrm{G}}$ & - & Different footprint area & {$[40]$} \\
\hline
\end{tabular}

\section{Results}

\subsection{Meteorological Conditions and Energy Budget Components}

From 23 January to 21 March, 2018, the mean daily air temperature on the Ulu Peninsula was $-2.5^{\circ} \mathrm{C}$ with a range from $-13.9^{\circ} \mathrm{C}$ to $5.3^{\circ} \mathrm{C}$. Daily mean air temperatures often changed from negative to positive, however, they were $<0^{\circ} \mathrm{C}$ after 25 February, with the exception of 28 February and 11 March (Figure 2d). On the other hand, the daily mean ground surface temperature was mostly positive before 28 February and mostly negative afterwards. The daily mean ground temperature at $50 \mathrm{~cm}$ was $-0.2{ }^{\circ} \mathrm{C}$, varying between -1.3 and $0.3{ }^{\circ} \mathrm{C}$ only. In $21 \%$ of the measurement period, the wind blew from south-southwest (Figure 1c), where the Bohemian Stream catchment lies. The highest mean daily wind speed of $13.6 \mathrm{~ms}^{-1}$ was measured on 15 March, 2018 during south-westerly wind (Figure 2e).

Mean albedo was 0.11 when the ground surface was bare, while it rose to 0.54 on the days with snow cover (Figure 2b). On 8 and 9 February, albedo increased to over 0.70 . Snow cover also intensified after 13 March and during 2-5 March, when 3-cm deep snow cover led to the albedo reaching 0.64 .

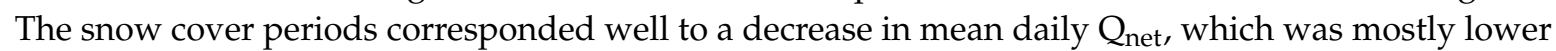
than $40 \mathrm{~W} \mathrm{~m}^{-2}$ during the intensified snow cover period and only reached $60 \mathrm{~W} \mathrm{~m}^{-2}$ on 3 March.

Mean $\mathrm{Q}_{\text {net }}$ was $102.5 \mathrm{~W} \mathrm{~m}^{-2}$ and mean $\mathrm{Q}_{\mathrm{L} \downarrow}\left(264.4 \mathrm{~W} \mathrm{~m}^{-2}\right)$ was by $45 \%$ higher than mean $\mathrm{Q}_{\mathrm{S} \downarrow}$ $\left(182.7 \mathrm{~W} \mathrm{~m}^{-2}\right)$. Mean $\mathrm{Q}_{\mathrm{L} \uparrow}$ was $311.1 \mathrm{Wm}^{-2}$, while mean $\mathrm{Q}_{\mathrm{S} \uparrow}$ was $33.4 \mathrm{Wm}^{-2}$ (Table A1). The highest energy budget component, apart from the radiation fluxes, was $\mathrm{Q}_{\mathrm{E}}$ with a mean value of $33.2 \mathrm{~W} \mathrm{~m}^{-2}$, closely followed by $\mathrm{Q}_{\mathrm{H}}\left(32.8 \mathrm{~W} \mathrm{~m}^{-2}\right)$. In both cases, standard deviations were about 1.5 times the mean value of the flux. The mean $Q_{G}$ was only $0.5 \mathrm{~W} \mathrm{~m}^{-2}$ due to the averaging-out of positive and negative $\mathrm{Q}_{\mathrm{G}}$ (Figure 2c). The residual term $\mathrm{C}$ reached $36.1 \mathrm{~W} \mathrm{~m}^{-2}$ as a mean value for the study period (more information in Table A1 and Figure A1).

Both mean $\mathrm{Q}_{\mathrm{H}}$ and $\mathrm{Q}_{\mathrm{E}}$ depended on wind direction (Figure 3). Their mean values were the lowest when the wind was from the east and south-south-east $\left(146.5^{\circ}\right.$ to $\left.168.5^{\circ}\right)$, while they were the highest for north-easterly and west-north-westerly wind $\left(281.5^{\circ}\right.$ to $\left.303.5^{\circ}\right)$. When the wind was westerly, both mean $\mathrm{Q}_{\mathrm{H}}$ and $\mathrm{Q}_{\mathrm{E}}$ increased with increasing wind speed (data not shown). Mean $\mathrm{Q}_{\mathrm{H}}$ was by $11.1 \mathrm{Wm}^{-2}$ higher than mean $\mathrm{Q}_{\mathrm{E}}$ for the south-south-westerly wind direction $\left(191.5^{\circ}\right.$ to $\left.213.5^{\circ}\right)$, while it was lower for easterly wind $\left(\mathrm{Q}_{\mathrm{H}}: 2.5 \mathrm{Wm}^{-2}, \mathrm{Q}_{\mathrm{E}}: 13.4 \mathrm{Wm}^{-2}\right)$ and for west-south-westerly to north-west-northerly wind $\left(236.5^{\circ}\right.$ to $348.5^{\circ}$, the difference between mean $\mathrm{Q}_{\mathrm{H}}$ and mean $\mathrm{Q}_{\mathrm{E}}$ of up to $\left.19.6 \mathrm{Wm}^{-2}\right)$. The $95 \%$ confidence intervals for both $\mathrm{Q}_{\mathrm{H}}$ and $\mathrm{Q}_{\mathrm{E}}$ were the lowest for south-south-westerly wind direction $\left(191.5^{\circ}\right.$ to $\left.213.5^{\circ}\right)$ and the highest for northerly and north-north-westerly wind direction for $\mathrm{Q}_{\mathrm{H}}$ and $\mathrm{Q}_{\mathrm{E}}$, respectively. It is, therefore, clear that in cases of low wind velocity (wind from the northerly sector), higher uncertainty on the closure of surface energy budget occurred and caused higher variation of both turbulent fluxes in the related wind directions. 

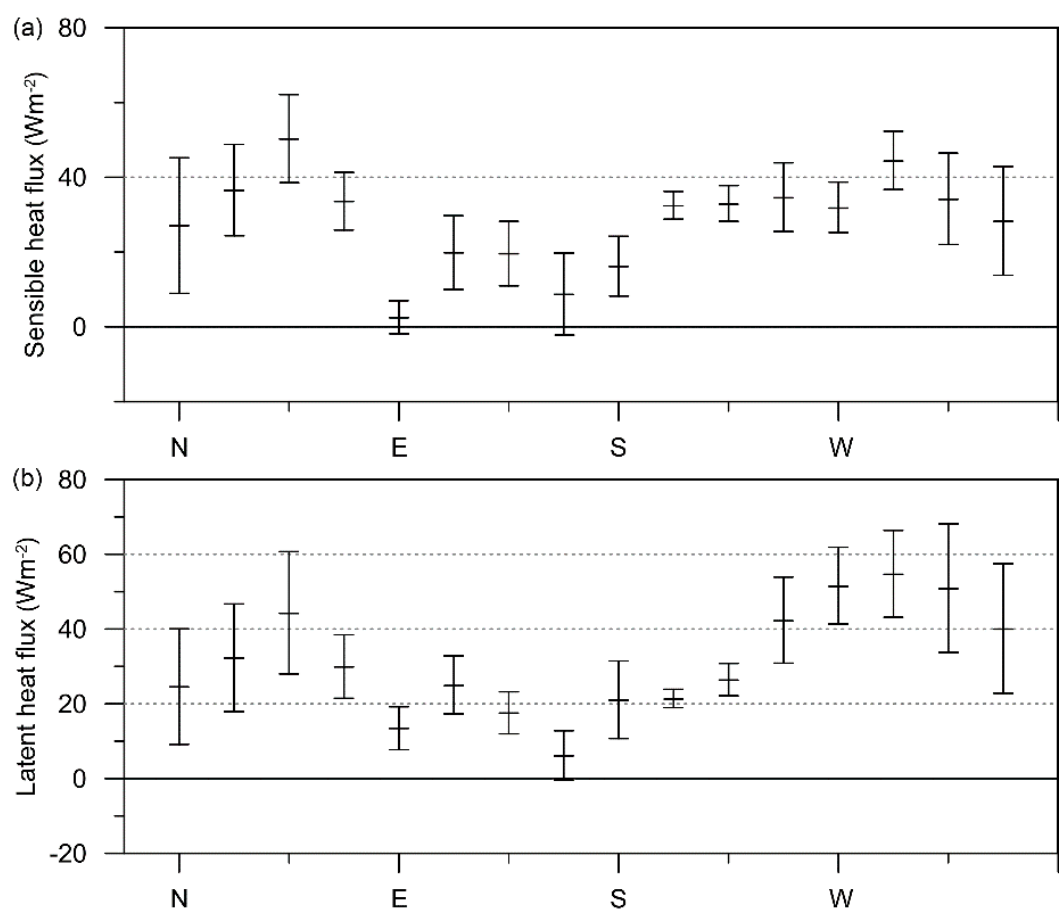

Figure 3. Mean and 95\% confidence interval of sensible heat flux (a) and latent heat flux (b) depending on wind direction at study site between 23 January and 21 March 2018.

\subsection{Ground Temperature Response to the Largest Surface Energy Fluxes}

The ground thermal regime was significantly influenced by individual components of the surface energy budget. Mean daily $\mathrm{Q}_{\mathrm{E}}$ was higher than $\mathrm{Q}_{\mathrm{H}}$ in $63 \%$ of the study period (Figure 2). The highest mean daily $\mathrm{Q}_{\mathrm{H}}$ was $100.1 \mathrm{~W} \mathrm{~m}^{-2}$ on 1 February (Figure 2). Between 31 January and 1 February, the daily mean ground surface temperature increased by $1.7^{\circ} \mathrm{C}$. Mean daily $\mathrm{Q}_{\mathrm{E}}$ was the highest on 24 February $\left(116.2 \mathrm{~W} \mathrm{~m}^{-2}\right)$, when $\mathrm{Q}_{\mathrm{H}}$ reached only $50.3 \mathrm{Wm}^{-2}$. A concurrent increase in air and ground surface temperature before 24 February pointed to active layer thawing (Figure 4). Between 24 and 25 February, the ground surface temperature decreased by $-5.8^{\circ} \mathrm{C}$, indicating that intense evaporation might have led to energy depletion in ground surface layers, which resulted in the drop in surface temperature.

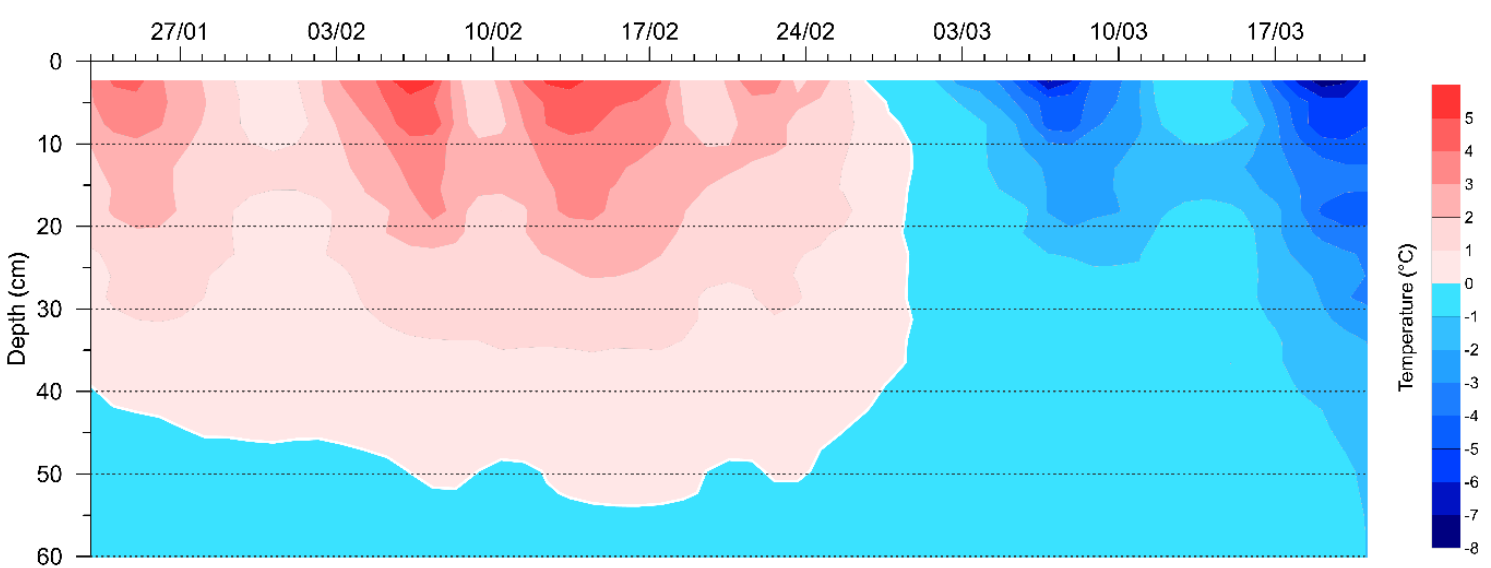

Figure 4. Ground temperature development at study site between 23 January and 21 March 2018. 
Daily mean $\mathrm{Q}_{\mathrm{G}}$ was the highest on 11 March, when it reached $23.9 \mathrm{~W} \mathrm{~m}^{-2}$. The $\mathrm{Q}_{\mathrm{G}}$ on 11 March led to warming of the whole column from the ground surface to a depth of about $30 \mathrm{~cm}$ (Figure 4), with daily mean ground surface temperatures rising by $5.3^{\circ} \mathrm{C}$ between 10 and $11 \mathrm{March}$, while the increase was by $0.2^{\circ} \mathrm{C}$ at a depth of $30 \mathrm{~cm}$. On 1 February, 24 February and $11 \mathrm{March}$, the change in daily mean ground temperature at a depth of $50 \mathrm{~cm}$ was never by more than $0.1^{\circ} \mathrm{C} \mathrm{day}^{-1}$, even though between 1 and 4 February there was a gradual increase of ground temperature at a depth of $50 \mathrm{~cm}$ observed.

Active layer refreezing at the end of the thawing season occurred during 26-28 February (Figure 4). It is clear from Figure 2 that, from 25 to 27 February, daily mean values of $Q_{G}$ were negative, resulting in a mean heat loss of $-5.9 \mathrm{~W} \mathrm{~m}^{-2}$. Such a negative mean three-day value of $\mathrm{Q}_{\mathrm{G}}$ had not been seen since the start of the measurement. It was also connected to the lowest three-day value of $Q_{\text {net }}$ since 23 January.

\subsection{Longer-Term Influence of Surface Energy Budget Components on Ground Temperature Variation}

Relationships between ground temperatures and surface energy budget components were the strongest for ground surface temperature and decreased with depth (Table 3). For $Q_{\text {net }}$, the highest correlation coefficients were 0.71 for ground surface temperature and ground temperature at a depth of $30 \mathrm{~cm}$. For $Q_{G}$, the difference between the strength of correlations with ground surface temperature and ground temperature at $30 \mathrm{~cm}$ was nearly 0.2 . For both $Q_{\text {net }}$ and $Q_{G}$, correlation coefficients were the highest without a lag for ground surface temperature. Correlation coefficients were close to zero for a depth of $75 \mathrm{~cm}$, which was connected to a nearly isothermal temperature regime with no daily and seasonal variation.

Table 3. Daily average correlation coefficients between ground surface temperatures $\left(\mathrm{T}_{\text {surf }}\right)$, ground temperatures at depth of $30 \mathrm{~cm}\left(\mathrm{GT}_{30}\right), 50 \mathrm{~cm}\left(\mathrm{GT}_{50}\right)$ and $75 \mathrm{~cm}\left(\mathrm{GT}_{75}\right)$ and net radiation $\left(\mathrm{Q}_{\text {net }}\right)$, ground heat flux $\left(\mathrm{Q}_{\mathrm{G}}\right)$ and air temperature $\left(\mathrm{T}_{\text {air }}\right)$ on James Ross Island during 23 January to 21 March 2018. The labels "0-3 days" correspond to the lag of ground temperature time series.

\begin{tabular}{cccccc}
\hline Variable 1 & Variable 2 & 0 Day & 1 Day & 2 Days & 3 Days \\
\hline Qnet vs. & $\mathrm{T}_{\text {surf }}$ & 0.71 & 0.66 & 0.64 & 0.59 \\
& $\mathrm{GT}_{30}$ & 0.52 & 0.70 & 0.71 & 0.68 \\
& $\mathrm{GT}_{50}$ & 0.48 & 0.64 & 0.67 & 0.64 \\
$\mathrm{Q}_{\mathrm{G}}$ vs. & $\mathrm{GT}_{75}$ & -0.15 & -0.08 & -0.01 & 0.01 \\
& $\mathrm{~T}_{\text {surf }}$ & 0.84 & 0.72 & 0.58 & 0.54 \\
& $\mathrm{GT}_{30}$ & 0.38 & 0.59 & 0.66 & 0.65 \\
& $\mathrm{GT}_{50}$ & 0.34 & 0.44 & 0.58 & 0.60 \\
$\mathrm{~T}_{\text {air }}$ vs. & $\mathrm{GT}_{75}$ & -0.01 & -0.02 & -0.02 & 0.05 \\
& $\mathrm{~T}_{\text {surf }}$ & 0.95 & 0.79 & 0.63 & 0.61 \\
& $\mathrm{GT}_{30}$ & 0.66 & 0.77 & 0.77 & 0.71 \\
& $\mathrm{GT}_{50}$ & 0.60 & 0.65 & 0.72 & 0.70 \\
& $\mathrm{GT}_{75}$ & -0.01 & -0.01 & 0.02 & 0.11 \\
\hline
\end{tabular}

Daily mean $\mathrm{Q}_{\mathrm{G}}$ also had several significant and strong relationships with other fluxes (Table 4). For instance, a significant anticorrelation between $\mathrm{Q}_{\mathrm{G}}$ and albedo meant that snow cover led to more negative $Q_{G}$, hence the flux from deeper levels towards the ground surface. Furthermore, there was a strong positive relationship between $\mathrm{Q}_{\mathrm{G}}$ and air temperature. Daily mean $\mathrm{Q}_{\mathrm{G}}$ could be expressed by the following regression functions:

$$
\mathrm{Q}_{\mathrm{G}}=5.7+2.1 \mathrm{~T}_{\mathrm{air}}
$$

and

$$
\mathrm{Q}_{\mathrm{G}}=-0.1+2.1 \mathrm{~T}_{\text {surf }}
$$

respectively. 
Table 4. Daily averages correlation matrix of shortwave downward radiation $\left(\mathrm{Q}_{\mathrm{S} \downarrow}\right)$, shortwave upward radiation $\left(\mathrm{Q}_{\mathrm{S} \uparrow}\right)$, longwave downward radiation $\left(\mathrm{Q}_{\mathrm{L} \downarrow}\right)$, longwave upward radiation $\left(\mathrm{Q}_{\mathrm{L} \uparrow}\right)$, net radiation $\left(Q_{\text {net }}\right)$, albedo, ground heat flux $\left(Q_{G}\right)$, sensible heat flux $\left(Q_{H}\right)$, latent heat flux $\left(Q_{E}\right)$, sum of fluxes $\left(\mathrm{Q}_{\mathrm{G}}+\mathrm{Q}_{\mathrm{H}}+\mathrm{Q}_{\mathrm{E}}\right)$ and air temperature $\left(\mathrm{T}_{\mathrm{air}}\right)$. Coefficients in bold are statistically significant on significance level of 0.05 . Study site and investigation period are the same as in Table 1.

\begin{tabular}{cccccccccccc}
\hline & $\mathrm{Q}_{\mathrm{S} \downarrow}$ & $\mathrm{Q}_{\mathrm{S} \uparrow}$ & $\mathrm{Q}_{\mathrm{L} \downarrow}$ & $\mathrm{Q}_{\mathrm{L} \uparrow}$ & $\mathrm{Q}_{\text {net }}$ & Albedo & $\mathrm{Q}_{\mathrm{G}}$ & $\mathrm{Q}_{\mathrm{H}}$ & $\mathrm{Q}_{\mathrm{E}}$ & $\mathrm{Q}_{\mathrm{G}}+\mathrm{Q}_{\mathrm{H}}+\mathrm{Q}_{\mathrm{E}}$ & $\mathrm{T}_{\text {air }}$ \\
\hline $\mathrm{Q}_{\mathrm{S} \downarrow}$ & 1.00 & -0.04 & -0.19 & $\mathbf{0 . 7 2}$ & $\mathbf{0 . 9 1}$ & $\mathbf{- 0 . 5 0}$ & $\mathbf{0 . 7 8}$ & $\mathbf{0 . 4 4}$ & $\mathbf{0 . 6 4}$ & $\mathbf{0 . 7 6}$ & $\mathbf{0 . 6 2}$ \\
\hline $\mathrm{Q}_{\mathrm{S} \uparrow}$ & -0.04 & 1.00 & $\mathbf{- 0 . 2 8}$ & $\mathbf{- 0 . 4 1}$ & $-\mathbf{0 . 3 3}$ & $\mathbf{0 . 7 6}$ & -0.20 & -0.19 & -0.16 & $\mathbf{- 0 . 3 0}$ & $\mathbf{- 0 . 3 4}$ \\
\hline $\mathrm{Q}_{\mathrm{L} \downarrow}$ & -0.19 & $\mathbf{- 0 . 2 8}$ & 1.00 & $\mathbf{0 . 3 0}$ & 0.02 & -0.15 & 0.02 & 0.20 & 0.20 & 0.24 & $\mathbf{0 . 3 4}$ \\
\hline $\mathrm{Q}_{\mathrm{L} \uparrow}$ & $\mathbf{0 . 7 2}$ & $\mathbf{- 0 . 4 1}$ & $\mathbf{0 . 3 0}$ & 1.00 & $\mathbf{0 . 7 9}$ & $\mathbf{- 0 . 6 5}$ & $\mathbf{0 . 8 5}$ & $\mathbf{0 . 3 4}$ & $\mathbf{0 . 8 1}$ & $\mathbf{0 . 8 3}$ & $\mathbf{0 . 9 6}$ \\
\hline $\mathrm{Q}_{\text {net }}$ & $\mathbf{0 . 9 1}$ & $\mathbf{- 0 . 3 3}$ & 0.02 & $\mathbf{0 . 7 9}$ & 1.00 & $\mathbf{- 0 . 7 1}$ & $\mathbf{0 . 7 6}$ & $\mathbf{0 . 6 0}$ & $\mathbf{0 . 7 2}$ & $\mathbf{0 . 8 7}$ & $\mathbf{0 . 6 7}$ \\
\hline albedo & $\mathbf{- 0 . 5 0}$ & $\mathbf{0 . 7 6}$ & -0.15 & $\mathbf{- 0 . 6 5}$ & $\mathbf{- 0 . 7 1}$ & 1.00 & $-\mathbf{0 . 5 4}$ & $\mathbf{- 0 . 2 9}$ & $\mathbf{- 0 . 4 1}$ & $\mathbf{- 0 . 5 6}$ & $\mathbf{- 0 . 5 3}$ \\
\hline $\mathrm{Q}_{\mathrm{G}}$ & $\mathbf{0 . 7 8}$ & -0.20 & 0.02 & $\mathbf{0 . 8 5}$ & $\mathbf{0 . 7 6}$ & $\mathbf{- 0 . 5 4}$ & 1.00 & 0.22 & $\mathbf{0 . 6 7}$ & $\mathbf{0 . 7 2}$ & $\mathbf{0 . 8 4}$ \\
\hline $\mathrm{Q}_{\mathrm{H}}$ & $\mathbf{0 . 4 4}$ & -0.19 & 0.20 & $\mathbf{0 . 3 4}$ & $\mathbf{0 . 6 0}$ & $\mathbf{- 0 . 2 9}$ & 0.22 & 1.00 & $\mathbf{0 . 5 0}$ & $\mathbf{0 . 7 1}$ & 0.18 \\
\hline $\mathrm{Q}_{\mathrm{E}}$ & $\mathbf{0 . 6 4}$ & -0.16 & 0.20 & $\mathbf{0 . 8 1}$ & $\mathbf{0 . 7 2}$ & $\mathbf{- 0 . 4 1}$ & $\mathbf{0 . 6 7}$ & $\mathbf{0 . 5 0}$ & 1.00 & $\mathbf{0 . 9 1}$ & $\mathbf{0 . 7 8}$ \\
\hline $\mathrm{Q}_{\mathrm{G}}+\mathrm{Q}_{\mathrm{H}}+\mathrm{Q}_{\mathrm{E}}$ & $\mathbf{0 . 7 6}$ & $\mathbf{- 0 . 3 0}$ & 0.24 & $\mathbf{0 . 8 3}$ & $\mathbf{0 . 8 7}$ & $\mathbf{- 0 . 5 6}$ & $\mathbf{0 . 7 2}$ & $\mathbf{0 . 7 1}$ & $\mathbf{0 . 9 1}$ & 1.00 & $\mathbf{0 . 7 5}$ \\
\hline $\mathrm{T}_{\text {air }}$ & $\mathbf{0 . 6 2}$ & $\mathbf{- 0 . 3 4}$ & $\mathbf{0 . 3 4}$ & $\mathbf{0 . 9 6}$ & $\mathbf{0 . 6 7}$ & $\mathbf{- 0 . 5 3}$ & $\mathbf{0 . 8 4}$ & 0.18 & $\mathbf{0 . 7 8}$ & $\mathbf{0 . 7 5}$ & 1.00 \\
\hline
\end{tabular}

Consequently, an increase in the summer air temperature of $1{ }^{\circ} \mathrm{C}$ would lead to an increase in summer $Q_{G}$ on JRI by $2.1 \mathrm{~W} \mathrm{~m}^{-2}$. The relationship between air temperature and ground surface temperature was even stronger than the relationship between air temperature and $\mathrm{Q}_{\mathrm{G}}$, as the correlation coefficient reached 0.95 (Table 3). The reason is that they both primarily respond to Qnet. Consistent with Fourier [42], the lag between $Q_{G}$ and ground temperature increased with depth. The correlations were quite high probably due to lack of vegetation cover and dry soil, enabling fast heat transport between air and the ground.

\subsection{Impact of Snow Cover and Cloudiness}

The impact of snow cover and cloudiness was studied with the use of day-long case studies representing contrasting situations that occurred during the summer season. On 4 March (Figure 5b), lower-than-average $\mathrm{Q}_{\mathrm{L} \uparrow}\left(-284.4 \mathrm{~W} \mathrm{~m}^{-2}\right)$ connected to low surface temperature $\left(-2.7^{\circ} \mathrm{C}\right)$ compensated for losses due to reflection from snow cover. $\mathrm{Q}_{\mathrm{L} \downarrow}$ was, for most of the time, $0-5 \mathrm{~W} \mathrm{~m}^{-2}$ higher compared with the average daily cycle (Figure 5a) due to the cloudy sky. $Q_{\text {net }}$ was below average apart from a short period between 1300 and 1400 local time when $Q_{S \downarrow}$ increased to $940 \mathrm{~W} \mathrm{~m}^{-2}$ because of a sudden reduction in cloud cover. Daily mean $\mathrm{Q}_{\mathrm{G}}$ on 4 March was $-12.7 \mathrm{~W} \mathrm{~m}^{-2}$, compared with the mean value of $0.4 \mathrm{~W} \mathrm{~m}^{-2}$ (Table 1). The decrease between 4 and 5 March was $-4.1^{\circ} \mathrm{C}_{\text {day }}{ }^{-1}$ for air temperature and $-4.9^{\circ} \mathrm{C} \mathrm{day}^{-1}$ for ground surface temperature (Figure 4). Consequently, both the surface and deeper ground levels were losing heat, despite the isolating effect of snow. 
(a)
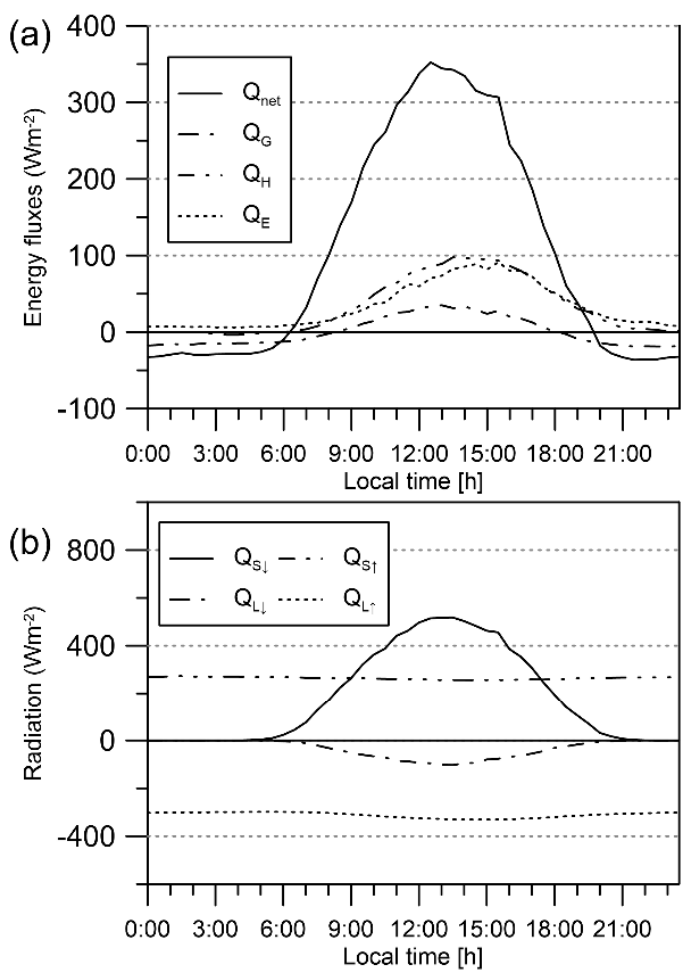

(c)

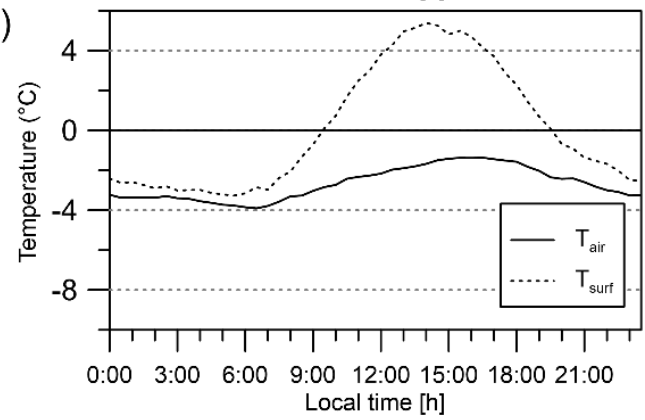

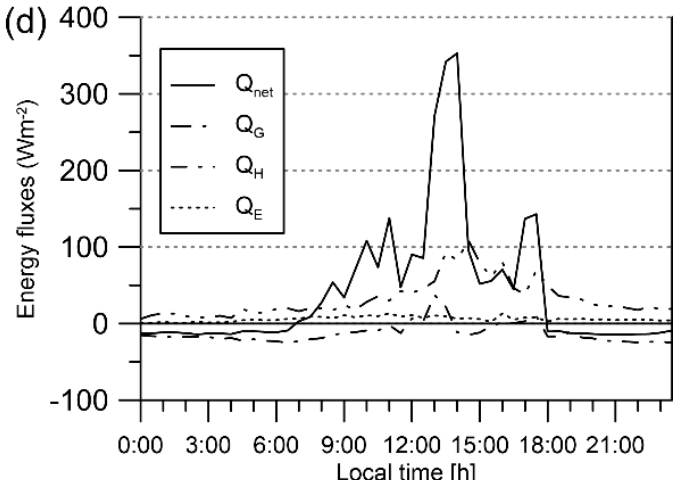

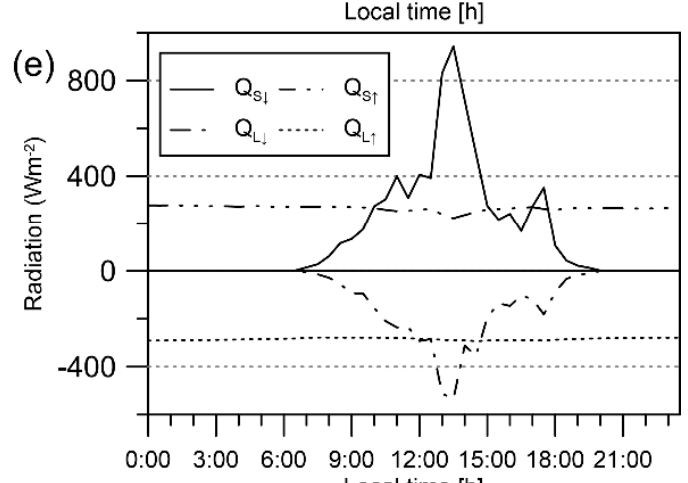

(f)

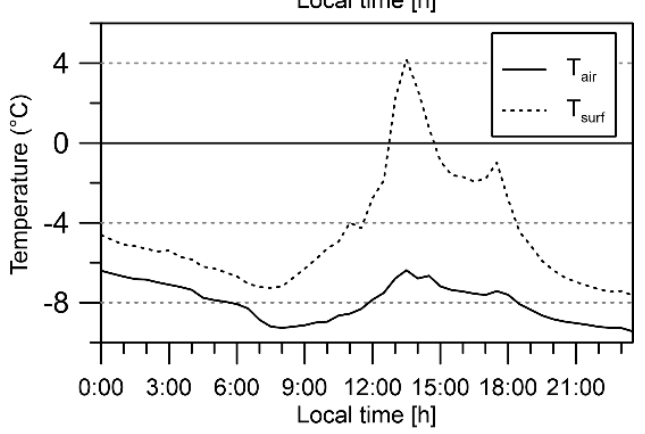

Figure 5. Daily regimes of surface energy budget components on James Ross Island between 23 January and 21 March 2018: averaged day (left column) and day with snow cover (right column, 4 March). $(\mathbf{a}, \mathbf{d})$ : net radiation $\left(\mathrm{Q}_{\text {net }}\right)$, ground heat flux $\left(\mathrm{Q}_{\mathrm{G}}\right)$, sensible heat flux $\left(\mathrm{Q}_{\mathrm{H}}\right)$ and latent heat flux $\left(\mathrm{Q}_{\mathrm{E}}\right)$. $(\mathbf{b}, \mathbf{e})$ : incoming shortwave radiation $\left(\mathrm{Q}_{\mathrm{S} \downarrow}\right)$, outgoing shortwave radiation $\left(\mathrm{Q}_{\mathrm{S} \uparrow}\right)$, incoming longwave radiation $\left(\mathrm{Q}_{\mathrm{L} \downarrow}\right)$ and outgoing longwave radiation $\left(\mathrm{Q}_{\mathrm{L} \uparrow}\right)$. $(\mathbf{c}, \mathbf{f})$ : air temperature $\left(\mathrm{T}_{\text {air }}\right)$ and ground surface temperature $\left(\mathrm{T}_{\text {surf }}\right)$.

The effect of cloudiness was studied on 18 and 15 February, when albedo $<0.1$ confirmed snow-free conditions. On the overcast day (18 February, Figure 6a), $\mathrm{Q}_{\mathrm{L} \downarrow}$ was, for most of the time, 10-25 W m ${ }^{-2}$ higher compared with the average daily cycle (Figure 5a). Daily mean $\mathrm{Q}_{\text {net }}$ was $44.8 \mathrm{~W} \mathrm{~m}^{-2}$ lower than on the averaged day. $Q_{G}$ responded to cloudiness by negative values apart from an increase to $10.5 \mathrm{~W} \mathrm{~m}^{-2}$ around 1400 . Consequently, the mean heat loss of the ground on 18 February was only $-11.3 \mathrm{~W} \mathrm{~m}^{-2}$, causing a drop of $2.4{ }^{\circ} \mathrm{C}$ in daily mean ground temperature at $10 \mathrm{~cm}$ depth (Figure 4 ). On the other hand, on 15 February, the sky was mostly clear apart from one episode of clouds evidenced by sudden decreases in $Q_{S \downarrow}$ at 1000 (Figure 6b). The large value of $Q_{S \downarrow}$ led to greater daily amplitudes of both $Q_{n e t}$ and $Q_{G}$ with daily means of $171.8 \mathrm{~W} \mathrm{~m}^{-2}$ and $6.4 \mathrm{~W} \mathrm{~m}^{-2}$, respectively. The supply of heat to the ground was reflected in ground temperature increases between 15 and 16 February from the surface down to $20 \mathrm{~cm}$ depth (Figure 4). A sudden increase in $Q_{E}$ at 1430 was connected to an increase of air temperature above $0^{\circ} \mathrm{C}$ (Figure $6 \mathrm{~b}$ ). 

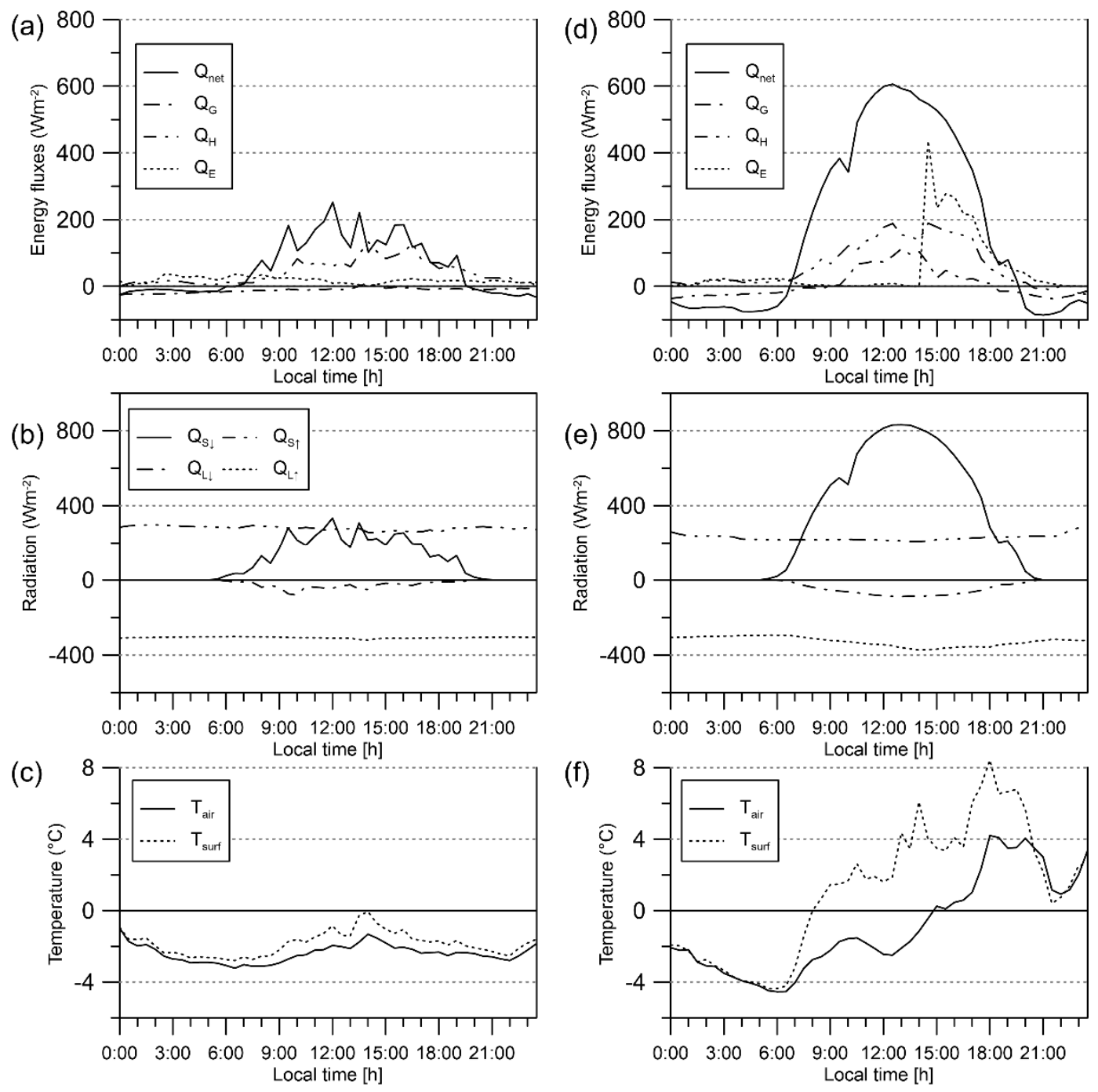

Figure 6. Daily regimes of surface energy budget components: day with overcast sky (left column, 18 February) and day with clear sky (right column, 15 February. (a,d): net radiation $\left(Q_{\text {net }}\right)$, ground heat flux $\left(\mathrm{Q}_{\mathrm{G}}\right)$, sensible heat flux $\left(\mathrm{Q}_{\mathrm{H}}\right)$ and latent heat flux $\left(\mathrm{Q}_{\mathrm{E}}\right)$. (b,e): incoming shortwave radiation $\left(\mathrm{Q}_{\mathrm{S} \downarrow}\right)$, outgoing shortwave radiation $\left(\mathrm{Q}_{\mathrm{S} \uparrow}\right)$, incoming longwave radiation $\left(\mathrm{Q}_{\mathrm{L} \downarrow}\right)$ and outgoing longwave radiation $\left(\mathrm{Q}_{\mathrm{L} \uparrow}\right)$. (c,f): air temperature $\left(\mathrm{T}_{\text {air }}\right)$ and ground surface temperature $\left(\mathrm{T}_{\text {surf }}\right)$.

\section{Discussion}

\subsection{Surface Energy Budget Components in Polar Regions}

The values of $Q_{n e t}, Q_{H}, Q_{E}$ and $Q_{G}$ from extant surface energy budget studies were only compared for February (Southern Hemisphere) and August (Northern Hemisphere) due to different lengths of measurement periods (Figure 7). Qnet on northern JRI for this month was $46-54 \%$ higher than on KGI [13] or dry tundra on Svalbard [43] or Axel Heiberg Island in northern Canada [44]. The only exception was the study from KGI by Prosek et al. [17] where $Q_{\text {net }}$ was only about $10 \%$ lower than on JRI. This can be attributed to higher cloudiness on the western side of the AP and a consequent decrease in $Q_{S \downarrow}$, as can be evidenced by a lower ratio of $Q_{\text {net }}$ to $Q_{S \downarrow}$ in this study (0.56) than in the study from KGI (0.62) by Choi et al. [13]. 


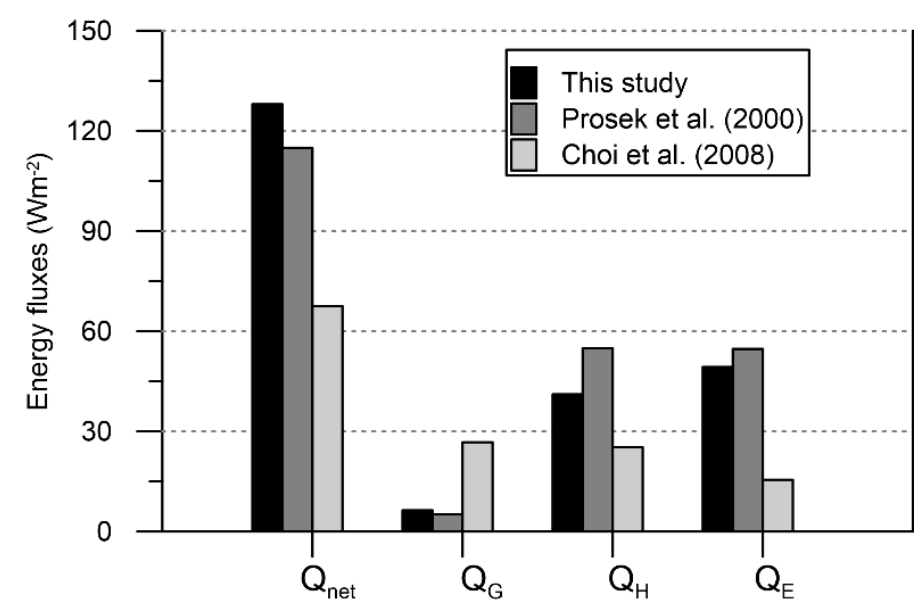

Figure 7. February mean net radiation $\left(\mathrm{Q}_{\text {net }}\right)$, ground heat flux $\left(\mathrm{Q}_{\mathrm{G}}\right)$, sensible heat flux $\left(\mathrm{Q}_{\mathrm{H}}\right)$ and latent heat flux $\left(\mathrm{Q}_{\mathrm{E}}\right)$ on James Ross Island (this study) and King George Island according to studies by Prosek et al. [17] and Choi et al. [13].

The value of $\mathrm{Q}_{\mathrm{G}}$ on JRI was also slightly higher than on KGI [17], however, in both cases, $\mathrm{Q}_{\mathrm{G}}$ comprised about $5 \%$ of $Q_{n e t}$ on average. The amount of $Q_{G}$ received by the soil decreases during summer in the ice-free polar regions (e.g., $[13,24,29,38]$ ), for instance by $-0.46 \mathrm{~W} \mathrm{~m}^{-2}$ per 10 days on KGI [17]. Therefore, it is possible that around summer solstice, the soil on JRI might have received up to $5 \mathrm{~W} \mathrm{~m}^{-2}$. The ratio of $Q_{\mathrm{G}}$ to $Q_{\text {net }}$ on JRI was 2-4 times lower than in dry Arctic tundra, where summer $\mathrm{Q}_{\mathrm{G}}$ usually formed $10-20 \%$ of $\mathrm{Q}_{\text {net }}$ (e.g., $\left.[23,45,46]\right)$, which could have been connected to differences in ground surface properties such as vegetation cover and polar day occurrence. In Choi et al. [13], $Q_{G}$ formed nearly $40 \%$ of $Q_{\text {net }}$ on KGI, but the value was most likely overestimated, as it also contained the residual term.

Both on JRI and KGI [17] in February, $Q_{H}$ was comparable to $Q_{E}$. Similar to dry Arctic tundra in late summer, $Q_{H}$ on JRI also formed about $30 \%$ of $Q_{\text {net }}$ (e.g., [44,47]). Summer $Q_{E}$ in the Arctic were higher than $\mathrm{Q}_{\mathrm{H}}$ by $20 \%$ to $100 \%$ [40] with the difference increasing as the autumn approached (Table 4 in $[24,48]$ ). That also seemed to be the case on JRI, as February mean $\mathrm{Q}_{\mathrm{E}}$ was about $20 \%$ higher than $\mathrm{Q}_{\mathrm{H}}$.

Mean $Q_{E}$ was higher than $Q_{H}$ (Figure 3) when the wind was from the westerly sector, while it was vice versa for the south-south-westerly wind. For the westerly sector, there was a clear influence of fetch from the Prince Gustav Channel, which was often free of sea ice. For the south-south-westerly wind, it is likely that measured $\mathrm{Q}_{\mathrm{E}}$ would be higher than calculated $\mathrm{Q}_{\mathrm{E}}$, as the ground is waterlogged in that direction (Figure 1).

\subsection{Surface Energy Budget Impact on Ground Thermal Regime}

The main heat source for ground warming on JRI was $Q_{\text {net }}$ and $Q_{S \downarrow}$, as evidenced by the co-occurrence of the most intensive ground warming with the largest $\mathrm{Q}_{\text {net }}$ (Figures 2 and 4). For the most part, $Q_{\text {net }}$ supplied heat to $Q_{G}$, both turbulent fluxes and ground warming. However, in $53 \%$ of the time, the ground was also contributing via $Q_{G}$ to warming the air, which also occasionally happened in the dry Arctic (western Greenland) [45]. On 11 March, $Q_{n e t}$ and $Q_{H}$ were the main energy sources, as the ground was cooler than the air above (Figure 2). On that day, the available energy was penetrating well via the frozen ground due to higher thermal conductivity of frozen compared to unfrozen ground, which led to slight ground warming (Figure 4). From the surface energy budget components, the closest relationship of ground temperature was found to be with $Q_{G}$.

The energy transfer via the ground was similar on the eastern and western sides of the AP, as demonstrated, for instance, by the correlations between $Q_{\text {net }}$ and ground temperatures on JRI (this study) and KGI [17]. At the measurement site on northern JRI, there was bare ground, while 
Prosek et al. [17] carried out measurements over regularly flooded ground covered with a 3-cm-thick vegetation cover consisting of $30 \%$ moss and $70 \%$ grass. It is, therefore, clear that the insulating effect of vegetation cover acted to delay the energy transfer, which might have consequently operated at the level of days rather than hours.

The specific climate conditions and the absence of vegetation cover on JRI study site strongly influenced the ground thermal regime, as the ground temperature at a depth of $10 \mathrm{~cm}$ was about $4{ }^{\circ} \mathrm{C}$ lower than for the corresponding period in Arctic lichen tundra (Figure 7 in [49]). The ground without vegetation on JRI cooled more during the night, when the ground temperature at a depth of $10 \mathrm{~cm}$ fell to $-0.4{ }^{\circ} \mathrm{C}$, compared with a minimum of $2.3^{\circ} \mathrm{C}$ in the Arctic.

The ground thawed and froze frequently both on JRI and KGI [17], but while Prosek et al. [17] observed refreezing of the whole active layer profile on KGI within 9 days, on JRI it was only 3 days.

\subsection{Snow Cover and Cloudiness Effects}

On JRI, the insulating effect of snow on $\mathrm{Q}_{\mathrm{G}}$ and the ground thermal regime was considered as rather negligible, both in this study and by Hrbacek et al. [50]. However, the maximum snow height reached only $26 \mathrm{~cm}$ during 23 January to 20 March, 2018 on JRI. Langer et al. [29] noticed that, at the Lena River Delta, the insulating effect was the most pronounced during winter, while, later in the year, the heat stored in the soil was depleted, meaning that snow insulation was of minor relevance. Furthermore, the high albedo of snow prevented the ground from receiving $\mathrm{Q}_{\mathrm{S} \downarrow}$ [44], which would have reduced ground cooling.

The radiation paradox [51] was not observed on JRI, as the effect of cloudiness was to cool the ground surface and soil layer, since the decrease in $Q_{\triangle \downarrow}$ was not compensated for by an increase in $\mathrm{Q}_{\mathrm{L} \downarrow}$. Such conditions also occurred in summer on Svalbard [52]. For individual days, the difference in $Q_{\text {net }}$ and $Q_{G}$, due to lower cloudiness on JRI, could have been up to 120 and $17.5 \mathrm{~W} \mathrm{~m}^{-2}$, respectively, while the difference in $Q_{n e t}$ was only $100 \mathrm{~W} \mathrm{~m}^{-2}$ across the tundra in Svalbard [43]. The cloud cover is usually less dense on the eastern side of the AP, as is documented, for instance, by the difference of $32 \mathrm{~W} \mathrm{~m}^{-2}$ in $\mathrm{Q}_{\mathrm{L} \downarrow}$ between this study and Hurd Peninsula glaciers on Livingston Island [14]. That could mean a significant increase in $Q_{n e t}$ and $Q_{G}$ on JRI with respect to the western side of the AP.

Neither the snow nor cloudiness affected $Q_{H}$ in summer significantly, both on the eastern and western sides of the AP [13]. One reason might have been that $\mathrm{Q}_{\mathrm{H}}$ responses to wind speed, as was shown earlier (Figure 3), and air-surface temperature differences, which do not always have to be connected to cloud cover development. Unlike on KGI [13], less energy was partitioned to $\mathrm{Q}_{\mathrm{E}}$ on the day with snow than on the day with extensive cloud cover.

\section{Conclusions}

In this study, the surface energy budget and its impact on the ground thermal regime were studied on JRI during January-March 2018. The main findings were:

- Mean $Q_{n e t}$ reached $102.5 \mathrm{~W} \mathrm{~m}^{-2}$, while the highest mean daily $\mathrm{Q}_{\text {net }}$ was $253 \mathrm{~W} \mathrm{~m}^{-2}$. Mean $\mathrm{Q}_{\mathrm{G}}$ was only $0.5 \mathrm{~W} \mathrm{~m}^{-2}$ and yet $46 \%$ of the time the ground was a heat source for the atmosphere. Mean $Q_{E}$ was only by $0.4 \mathrm{Wm}^{-2}$ higher than mean $Q_{H}$. Mean $Q_{E}$ was up to $19.6 \mathrm{~W} \mathrm{~m}^{-2}$ higher than mean $\mathrm{Q}_{\mathrm{H}}$ when the wind blew from west-south-westerly to north-west-northerly sector $\left(236.5^{\circ}\right.$ to $\left.348.5^{\circ}\right)$, showing the influence of increased moisture availability from the sea.

- The ground thermal regime was affected by surface energy budget components to the depth of $50 \mathrm{~cm}$. The strongest relationship was found between $Q_{G}$ and the ground surface temperature, with a delay growing along with increasing depth. The active layer refroze at the end of February after a sequence of three days with continuously negative $Q_{G}$.

- The case studies have shown that an increase of cloud cover led to a decrease of both mean daily $Q_{\text {net }}$ and $Q_{G}$ which caused cooling in ground thermal profile. On a clear-sky day, the situation was vice versa. 
- Insulation by snow cover was not observed, as $\mathrm{Q}_{\mathrm{G}}$ was $13.2 \mathrm{~W} \mathrm{~m}^{-2}$ below average and the ground was cooling in the whole profile during a sample day with snow cover.

- By comparison with other studies, we concluded that $Q_{n e t}$ was higher on the eastern side of the AP due to less cloudiness affected by regional atmospheric patterns. Mean $Q_{G}$ reached similar values on the eastern and western side of the AP and comprised about $5 \%$ of $Q_{\text {net }}$, approximately four-times less than was observed in the Arctic summer months. Mean $\mathrm{Q}_{\mathrm{E}}$ was, on both sides of the $\mathrm{AP}$, approximately the same as $\mathrm{Q}_{\mathrm{H}}$, even though the ratio of $\mathrm{Q}_{\mathrm{H}}$ to $\mathrm{Q}_{\text {net }}$ varied by $15 \%$ among the studies.

Summer energy fluxes $\left(\mathrm{Q}_{\mathrm{H}}\right.$ and $\left.\mathrm{Q}_{\mathrm{E}}\right)$ are crucial for the AP glaciers due to warming effect and efficient snow and ice melting (e.g., $[9,14])$, although they were mostly heat sources for the atmosphere in our study site. Ice-free areas might, accordingly, be an important source of energy in the AP region and should be considered in regional climate models. As all the surface energy budget studies from ice-free regions in Antarctica so far have only been seasonal, a deeper understanding of the surface energy budget would be gained from a full-year data set. The reported climate evolution of the AP region is currently slightly uncertain [8]. Should the warming observed since the 1950s continue, existing ice-free areas are more likely to be enlarged. Consequently, a study of the interannual and spatial variability in the surface energy budget in ice-free areas in Antarctica would provide valuable new information about how these new environments might influence the land-atmosphere interactions and the future climate of Antarctica.

The data that support the findings of this study are available from the corresponding author upon reasonable request.

Author Contributions: Conceptualization, K.L.; Data curation, F.H.; Investigation, K.A.; Supervision, K.L.; Visualization, K.A.; Writing —original draft, K.A.; Writing—review \& editing, F.H. and K.L. All authors have read and agreed to the published version of the manuscript.

Funding: This study was supported by the Czech Science Foundation projects (GC16-14122J and GA20-20240S) and the Czech Polar Research Infrastructure project (LM2015078) funded by the Ministry of Education, Youth and Sports of the Czech Republic. The article also contributes to the project of Masaryk University MUNI/A/1576/2018 and ECOPOLARIS project (CZ.02.1.01/0.0/0.0/16_013/0001708).

Acknowledgments: The authors are grateful to expedition members and crew of the J. G. Mendel Station in January-February 2018 who helped with set-up and maintenance of the measuring equipment. Special thanks belong to Moritz Langer and Jan Jekl for their help with the calculation of the latent heat flux.

Conflicts of Interest: The authors declare no conflict of interest.

\section{Appendix A}

Table A1. Mean values and 95\% confidence interval of selected meteorological variables on James Ross Island during 23 January to 21 March 2018. Shortcuts explanation: shortwave downward radiation $\left(\mathrm{Q}_{\mathrm{S} \downarrow}\right)$, shortwave upward radiation $\left(\mathrm{Q}_{\mathrm{\uparrow} \uparrow}\right)$, longwave downward radiation $\left(\mathrm{Q}_{\llcorner\downarrow}\right)$, longwave upward radiation $\left(\mathrm{Q}_{\mathrm{L} \uparrow}\right)$, net radiation $\left(\mathrm{Q}_{\text {net }}\right)$, albedo, ground heat flux $\left(\mathrm{Q}_{\mathrm{G}}\right)$, sensible heat flux $\left(\mathrm{Q}_{\mathrm{H}}\right)$, latent heat flux $\left(\mathrm{Q}_{\mathrm{E}}\right)$, air temperature $\left(\mathrm{T}_{\text {air }}\right)$, ground surface temperature $\left(\mathrm{T}_{\text {surf }}\right)$ and ground temperature at depth of $50 \mathrm{~cm}\left(\mathrm{GT}_{50}\right)$.

\begin{tabular}{cccccc}
\hline $\mathrm{Q}_{\mathrm{S} \downarrow}\left(\mathrm{Wm}^{-2}\right)$ & $\mathrm{Q}_{\mathrm{S} \uparrow}\left(\mathrm{Wm}^{-2}\right)$ & $\mathrm{Q}_{\mathrm{L} \downarrow}\left(\mathrm{Wm}^{-2}\right)$ & $\mathrm{Q}_{\mathrm{L} \uparrow}\left(\mathrm{Wm}^{-2}\right)$ & $\mathrm{Q}_{\text {net }}\left(\mathrm{Wm}^{-2}\right)$ & Albedo \\
\hline $182.7 \pm 9.3$ & $33.4 \pm 2.2$ & $264.4 \pm 1.2$ & $311.1 \pm 1.1$ & $102.5 \pm 7.2$ & $0.25 \pm 0.06$ \\
\hline $\mathrm{Q}_{\mathrm{G}}\left(\mathrm{Wm}^{-2}\right)$ & $\mathrm{Q}_{\mathrm{H}}\left(\mathrm{Wm}^{-2}\right)$ & $\mathrm{Q}_{\mathrm{E}}\left(\mathrm{Wm}^{-2}\right)$ & $\mathrm{T}_{\text {air }}\left({ }^{\circ} \mathrm{C}\right)$ & $\mathrm{T}_{\text {surf }}\left({ }^{\circ} \mathrm{C}\right)$ & $\mathrm{GT}_{50}\left({ }^{\circ} \mathrm{C}\right)$ \\
\hline $0.5 \pm 1.1$ & $32.8 \pm 2.0$ & $33.2 \pm 2.3$ & $-2.5 \pm 0.2$ & $0.1 \pm 0.2$ & $-0.2 \pm 0.0$ \\
\hline
\end{tabular}




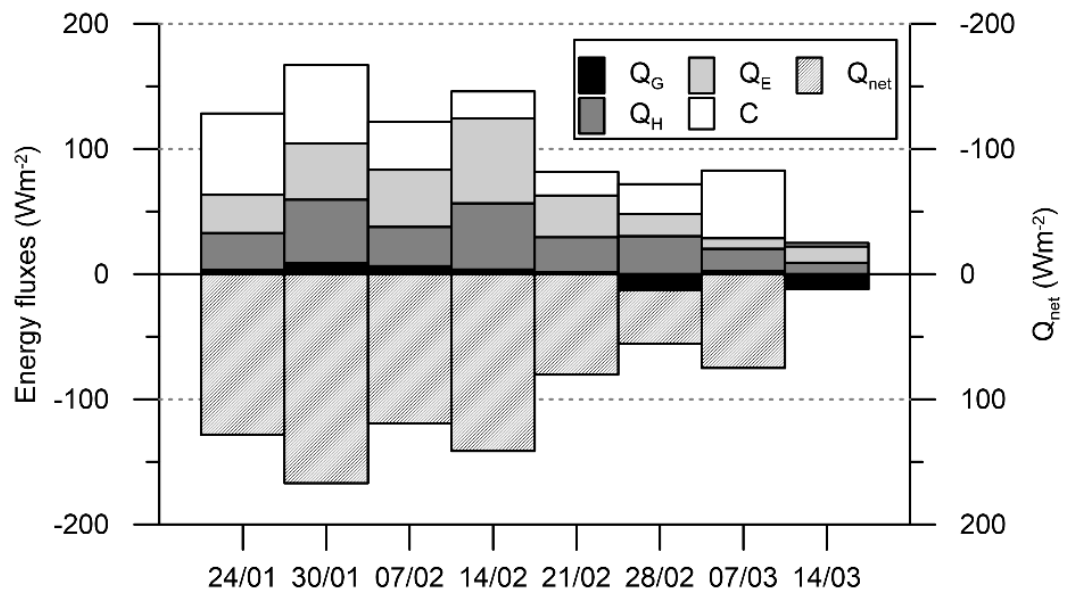

Figure A1. Weekly averages of net radiation $\left(Q_{\text {net }}\right)$, ground heat flux $\left(Q_{G}\right)$, sensible heat flux $\left(Q_{H}\right)$, latent heat flux $\left(\mathrm{Q}_{\mathrm{E}}\right)$ and residual term $(\mathrm{C})$.

\section{References}

1. King, J.C.; Turner, J. Antarctic Meteorology and Climatology; Cambridge University Press: Cambridge, UK, 1997; pp. 1-425.

2. Burton-Johnson, A.; Black, M.; Fretwell, P.T.; Kaluza-Gilbert, J. An automated methodology for differentiating rock from snow, clouds and sea in Antarctica from Landsat 8 imagery: A new rock outcrop map and area estimation for the entire Antarctic continent. Cryosphere 2016, 10, 1665-1677. [CrossRef]

3. Fox, A.J.; Cooper, A.P.R. Climate-change indicators from archival aerial photography of the Antarctic Peninsula. Ann. Glaciol. 1998, 27, 636-642. [CrossRef]

4. ATCM. Antarctic Trial of WWF's Rapid Assessment of Circum-Arctic Ecosystem Resilience (RACER) Conservation Planning Tool: Results of RACER Workshop Focused on James Ross Island. Information paper by Great Britain and Czechia. In Proceedings of the 38th Antarctic Treaty Consultative Meeting, Sofia, Bulgaria, 14 December 2015.

5. Lee, J.R.; Raymond, B.; Bracegirdle TJChadès, I.; Fuller, R.A.; Shaw, J.D.; Terauds, A. Climate change drives expansion of Antarctic ice-free habitat. Nature 2017, 547, 49-54. [CrossRef] [PubMed]

6. Turner, J.; Lu, H.; White, I.; King, J.C.; Phillips, T.; Hosking, J.S.; Bracegirdle, T.J.; Marshall, G.J.; Mulvaney, R.; Deb, P. Absence of 21st century warming on Antarctic Peninsula consistent with natural variability. Nature 2016, 535, 411-415. [CrossRef]

7. Oliva, M.; Navarro, F.; Hrbacek, F.; Hernández, A.; Nývlt, D.; Pereira, P.; Ruiz-Fernández, J.; Trigo, R. Recent regional climate cooling on the Antarctic Peninsula and associated impacts on the cryosphere. Sci. Total Environ. 2017, 580, 210-223. [CrossRef]

8. Gonzalez, S.; Fortuny, D. How robust are the temperature trends on the Antarctic Peninsula? Antarct. Sci. 2018, 30, 322-328. [CrossRef]

9. Bintanja, R. The local surface energy balance of the Ecology Glacier, King George Island, Antarctica: Measurements and modelling. Antarct. Sci. 1995, 7, 315-325. [CrossRef]

10. Braun, M.; Saurer, H.; Vogt, S.; Simões, J.C.; Goßmann, H. The Influence of Large-Scale Atmospheric Circulation on the Surface Energy Balance of the King George Island Ice Cap. Int. J. Climatol. 2001, 21, 21-36. [CrossRef]

11. King, J.C.; Argentini, S.A.; Anderson, P.S. Contrasts between the summertime surface energy balance and boundary layer structure at Dome C and Halley stations, Antarctica. J. Geophys. Res. 2006, 11, D02105. [CrossRef]

12. Vihma, T.; Johansson, M.M.; Launiainen, J. Radiative and turbulent surface heat fluxes over sea ice in the western Weddell Sea in early summer. J. Geophys. Res. 2009, 114, C04019. [CrossRef]

13. Choi, T.; Lee, B.Y.; Kim, S.-J.; Yoon, Y.J.; Lee, H.-C. Net radiation and turbulent energy exchanges over a non-glaciated coastal area on King George Island during four summer seasons. Antarct. Sci. 2008, 20, 99-111. [CrossRef] 
14. Jonsell, U.Y.; Navarro, F.J.; Bañón, M.; Lapazaran, J.J.; Otero, J. Sensitivity of a distributed temperature-radiation index melt model based on AWS observations and surface energy balance fluxes, Hurd Peninsula glaciers, Livingston Island, Antarctica. Cryosphere 2012, 6, 539-552. [CrossRef]

15. Alves, M.; Soares, J. Diurnal Variation of Soil Heat Flux at an Antarctic Local Area during Warmer Months. Appl. Environ. Soil. Sci. 2016, 2016, 9. [CrossRef]

16. Perrson, P.O.G.; Stone, R.S.; Grachev, A.; Matrosova, L. Processes Affecting the Annual Surface Energy Budget at High-Latitude Terrestrial Sites. In Proceedings of the EGU Conference, Vienna, Austria, 22-27 April 2012.

17. Prosek, P.; Janouch, M.; Láska, K. Components of the energy balance of the ground surface and their effect of the thermics of the substrata of the vegetation oasis at Henryk Arctowski Station, King George Island, South Shetland Islands. Polar Rec. 2000, 36, 3-18. [CrossRef]

18. Foken, T. The Energy Balance Problem: An Overview. Ecol. Appl. 2008, 18, 1351-1367. [CrossRef]

19. Lunardini, V.J. Heat Transfer in Cold Climates; Van Nostrand-Reinhold: New York, NY, USA, 1981; pp. 1-731.

20. Roth, K.; Boike, J. Quantifying the thermal dynamics of a permafrost site near Ny-Ålesund, Svalbard. Water Resour. Res. 2001, 37, 2901-2914. [CrossRef]

21. Williams, P.J.; Smith, M.W. The Frozen Earth: Fundamentals of Geocryology; Cambridge University Press: Cambridge, UK, 1989; pp. 1-306.

22. Ling, F.; Zhang, T. A numerical model for surface energy balance and thermal regime of the active layer and permafrost containing unfrozen water. Cold Reg. Sci. Technol. 2004, 38, 1-15. [CrossRef]

23. Hrbáček, F.; Kňažková, M.; Nývlt, D.; Láska, K.; Mueller, C.W.; Ondruch, J. Active layer monitoring at CALM-S site near J. G. Mendel Station, James Ross Island, eastern Antarctic Peninsula. Sci. Total Environ. 2017, 601-602, 987-997. [CrossRef] [PubMed]

24. Eugster, W.; Rouse, W.R.; Pielke, R.A.; Mcfadden, J.P.; Baldocchi, D.D.; Kittel, T.G.; Chapin, I.I.I.F.S.; Liston, G.E.; Vidale, P.L.; Vaganov, E.; et al. Land-atmosphere energy exchange in Arctic tundra and boreal forest: Available data and feedbacks to climate. Glob. Chang. Biol. 2000, 6, 84-114. [CrossRef]

25. Van Wessem, J.M.; Reijmer, C.H.; Van de Berg, W.J.; van Den Broeke, M.R.; Cook, A.J.; van Ulft, L.H.; van Meijgaard, E. Temperature and wind climate of the Antarctic Peninsula as simulated by a high-resolution regional atmospheric climate mode. J. Clim. 2015, 28, 7306-7326. [CrossRef]

26. Kavan, J.; Ondruch, J.; Nývlt, D.; Hrbáček, F.; Carrivick, J.L.; Láska, K. Seasonal hydrological and suspended sediment transport dynamics in proglacial streams, James Ross Island, Antarctica. Geogr. Ann. A 2017, 99, 38-55. [CrossRef]

27. Bohuslavová, O.; Macek, P.; Redčenko, O.; Láska, K.; Nedbalová, L.; Elster, J. Dispersal of lichens along a successional gradient after deglaciation of volcanic mesas on northern James Ross Island, Antarctic Peninsula. Polar Biol. 2018, 41, 2221-2232. [CrossRef]

28. Hrbáček, F.; Oliva, M.; Láska, K.; Ruiz-Fernández, J.; De Pablo, M.A.; Vieira, G.; Ramos, M.; Nývlt, D. Active layer thermal regime in two climatically contrasted sites of the Antarctic Peninsula region [Régimen termal de la capa activa en dos áreas climáticamente. contrastadas de la Península Antártica]. Cuad. Investig. Geogr. 2016, 42, 457-474.

29. Langer, M.; Westermann, S.; Muster, S.; Piel, K.; Boike, J. The surface energy balance of a polygonal tundra site in northern Siberia-Part 1: Spring to fall. Cryosphere 2011, 5, 151-171. [CrossRef]

30. Wilks, D. Statistical Methods in the Atmospheric Sciences; Academic Press: Cambridge, MA, USA, 2011; pp. 1-704.

31. Fuchs, M. Heat flux. In Methods of Soil Analysis. Part I. Physical and Mineralogical Methods, 2nd ed.; Klute, A., Ed.; SSSA Book Series no. 5; SSSA: Madison, WI, USA, 1986; pp. 957-968.

32. Sauer, T.J.; Horton, R. Micrometeorology in Agricultural Systems. Agronomy Monograph no. 47; American Society of Agronomy, Crop Science Society of America; Soil Science Society of America: Madison, WI, USA, 2005; pp. 1-154.

33. Foken, T. Micrometeorology; Springer: Berlin/Heidelberg, Germany, 2008; pp. 1-1306.

34. Liu, H.; Foken, T. A modified Bowen ratio method to determine sensible and latent heat fluxes. Meteorol. Z. 2001, 10, 71-80. [CrossRef]

35. Gromke, C.; Manes, C.; Walter, B.; Lehning, M.; Guala, M. Aerodynamic Roughness Length of Fresh Snow. Bound-Layer Meteorol. 2011, 141, 21-34. [CrossRef]

36. Liu, C.; Li, Y.; Yang, Q.; Wang, L.; Wang, X.; Li, S.; Gao, Z. On the surface fluxes characteristics and roughness lengths at Zhongshan station, Antarctica. Int. J. Digit. Earth 2019, 12, 878-892. [CrossRef] 
37. Harrison, R.G. Meteorological Measurements and Instrumentation; Wiley Blackwell: Chichester, UK, 2015; pp. 1-257.

38. Westermann, S.; Lüers, J.; Langer, M.; Piel, K.; Boike, J. The annual surface energy budget of a high-arctic permafrost site on Svalbard, Norway. Cryosphere 2009, 3, 245-263. [CrossRef]

39. Ambrozova, K.; Laska, K.; Hrbacek, F.; Kavan, J.; Ondruch, J. Air temperature and lapse rate variation in the ice-free and glaciated areas of northern James Ross Island, Antarctic Peninsula, during 2013-2016. Int. J. Climatol. 2019, 39, 643-657. [CrossRef]

40. Wilson, K.; Goldstein, A.; Falge, E.; Aubinet, M.; Baldocchi, D.; Berbigier, P.; Bernhofer, C.; Ceulemans, R.; Dolman, H.; Field, C.; et al. Energy balance closure at FLUXNET sites. Agric. Meteorol. 2002, 113, $223-243$. [CrossRef]

41. Burba, G.; Anderson, D. A Brief Practical Guide to Eddy Covariance Flux Measurements: Principles and Workflow Examples for Scientific and Industrial Applications; LI-COR Biosciences: Lincoln, NE, USA, 2010; 212p.

42. Fourier, J. The Analytical Theory of Heat; Dover Publications: New York, NY, USA, 1955; pp. 1-66.

43. Kejna, M.; Przybylak, R.; Araźny, A. The Influence of Cloudiness and Synoptic Situations on the Solar Radiation Balance in the Area of Kaffiøyra (NW Spitsbergen) in the Summer Seasons 2010 and 2011. Bull. Geogr. Phys. Geogr. Ser. 2012, 5, 77-95. [CrossRef]

44. Ohmura, A. Comparative Energy Balance Study for Arctic Tundra, Sea Surface, Glaciers and Boreal Forests. Geojournal 1984, 8, 221-228. [CrossRef]

45. Rott, H.; Obleitner, F. The Energy Balance of Dry Tundra in West Greenland. Arct. Alp. Res. 1992, 24, 352-362. [CrossRef]

46. Harding, R.J.; Lloyd, C.R. Fluxes of water and energy from high latitude tundra sites in Svalbard. Nord. Hydrol. 1998, 29, 267-284. [CrossRef]

47. Scherrer, D.; Parlow, E.; Ritter, N.; Siegrist, F. Klimaoökologie und Fernerkundung. In Methoden und Datenübersicht der Forschungsgruppen der Geowissenschaftlichen Spitzbergen-Expeditionen 1990 und 1991 zum Liefdefjorden (Datenband) Materialien zur Physiogeographie; Leser, H., Ed.; Geographisches Institut: Basel, Switzerland, 1993; Volume 15, pp. 51-58; appendix 121-151.

48. Sjøblom, A. Turbulent fluxes of momentum and heat over land in the High-Arctic summer: The influence of observation techniques. Polar Res. 2014, 33, 1-17. [CrossRef]

49. Migała, K.; Wojtuń, B.; Szymański, W.; Muskała, P. Soil moisture and temperature variation under different types of tundra vegetation during the growing season: A case study from the Fuglebekken catchment, SW Spitsbergen. Catena 2014, 116, 10-18. [CrossRef]

50. Hrbáček, F.; Láska, K.; Engel, Z. Effect of Snow Cover on the Active-Layer Thermal Regime-A Case Study from James Ross Island, Antarctic Peninsula. Permafr. Periglac. Process. 2016, 27, 307-315. [CrossRef]

51. Ambach, W. The Influence of Cloudiness on the Net Radiation Balance of a Snow Surface with High Albedo. J. Glaciol. 1974, 13, 73-84. [CrossRef]

52. Kejna, M.; Maturilli, M.; Araźny, A.; Sobota, I. Radiation balance diversity on NW Spitsbergen in 2010-2014. Pol. Polar Res. 2017, 39, 61-82. [CrossRef]

(C) 2020 by the authors. Licensee MDPI, Basel, Switzerland. This article is an open access article distributed under the terms and conditions of the Creative Commons Attribution (CC BY) license (http://creativecommons.org/licenses/by/4.0/). 